G A R Y H. JEFFER S O N

Brandeis University

ALBERT G. Z . H U

National University of Singapore

J I A N S U

Peking University

\title{
The Sources and Sustainability of China's Economic Growth
}

IN 1978, AT THE outset of its economic reform, China was the world's tenthlargest economy, with a GDP of about $\$ 150$ billion, or less than 6 percent of U.S. GDP at the time. By 2005, however, China's economy, at $\$ 2.2$ trillion, had grown to become the fourth largest in the world, behind only the United States at $\$ 12.5$ trillion, Japan at $\$ 4.5$ trillion, and Germany at $\$ 2.8$ trillion. The above figures, which come from the World Bank, evaluate GDP at current exchange rates and do not take account of differences in the purchasing power of currencies. When measured instead at purchasing power parity (PPP), China is already the world's second-largest economy, with almost $\$ 9$ trillion in output, nearly three quarters that of the United States. It has been suggested that, at current growth rates, China's GDP stated in PPP terms could exceed that of the United States as early as $2010 .{ }^{1}$

When China's GDP converted at current exchange rates does match that of the United States, assuming that China's population remains four times the U.S. population, Chinese income per capita will then be but one quarter that of the United States. By comparison, the purchasing power of the average Chinese resident will substantially exceed one quarter that of the average U.S. resident, perhaps rising to the vicinity of one half.

The authors appreciate their research collaboration with China's National Bureau of Statistics and specifically with its staff members Liu Yaodong and Qian Jinchang, who helped with data formatting and offered guidance on aspects of the research presented in this paper. We also appreciate the excellent research assistance of Sun Xiaole and Zhao Yan, doctoral candidates at the International Business School at Brandeis University. We acknowledge the support provided by the National Science Foundation (award no. SES-0519902) that helped support the research assistance provided to this project. Finally, comments provided by Barry Bosworth and Gustav Ranis during the panel session were most helpful for revising the paper.

1. See, for example, Holz (2006, p. 41). 
What changes will have to occur within China's productive sectors for China's GDP to match and ultimately surpass that of the United States? Today even China's coastal industry, the country's most technologically advanced region and sector, lags substantially behind the world technology frontier. Meanwhile a well-known feature of China's rapid economic transformation is the unequal advance, in terms of technological change and productivity, of different regions and sectors across this large and populous country. The regions and sectors that lag behind China's coastal industry also exhibit large disparities in productivity among themselves.

These large international and internal productivity gaps represent both advantages and disadvantages for China's ability to sustain high rates of GDP growth. The key advantage is that both the international gap and the internal gaps continue to provide multiple channels through which catch-up can proceed. A well-known disadvantage of the internal gaps is that the accompanying large differences in income threaten social stability. A further disadvantage of large internal productivity differences, to the extent they prove persistent, is that much of the burden of China's catch-up with the United States will fall on coastal industry. That is, if productivities in the regions and sectors outside China's coastal industry remain far below one quarter that of the United States, then coastal industry will have to achieve productivity levels well above one quarter that of the United States. Coastal industry will have to continue as the locomotive pulling the rest of the economy forward. Indeed, if China is to meet its ambitious goal of output parity with the United States, productivity in coastal industry may have to closely approach or even exceed U.S. productivity. Yet the history of other successful developing countries suggests that, as it does so, China's productivity growth is likely to slow substantially, in turn slowing the country's overall economic growth.

A number of questions emerge from this overview and frame the analysis in this paper: Within China, how much does China's coastal industry lag behind the global frontier? How much do China's other regions and sectors lag behind coastal industry? Is there evidence of catch-up or convergence of these regions and sectors with coastal industry? If so, what are the sources of such change? If instead there are growing disparities, what are the causes? To what extent can one expect that, as China's coastal industry closes in on the global technology frontier, the productivity growth of China's own technology frontier will slow? 
We investigate these questions using panels of industry and firmlevel data. However, any research agenda that seeks to assess a country's medium- to long-term economic growth prospects has to take into account that country's capacity for institutional adaptation, since institutions shape the incentives and prospects for such growth. This is particularly true for China, which remains engaged in two transitions simultaneously: from a centrally planned to a market economy, and from a less to a more developed country. Therefore we also speculate as to what institutional reforms will most directly bear on China's ability to close its international and internal productivity gaps. These reforms depend on the ability of China's political system to formulate and enforce the rules that reassign and clarify the property rights needed to sustain investment in technology development and to facilitate the flow of resources to the regions and sectors offering high returns.

During the past quarter century of reform, and largely to the surprise of most observers, China's economic performance has demonstrated considerable resilience. In addition to successfully weathering the Asian financial crises of the late 1990s, China has substantially restructured its state enterprise sector and opened itself to the international economy, including by having adopted World Trade Organization (WTO) rules. For two decades now China has sustained an annual average rate of growth of GDP about 6 percentage points higher than that of the United States (about 9 percent versus 3 percent). If China can sustain that growth advantage into the future, then, assuming no change in exchange rates, its GDP unadjusted for PPP will catch up to that of the United States in twenty-five to thirty years.

When China's GDP does catch up to U.S. GDP, that fact will be of more than symbolic importance. Having established an economic system that is as large, if not as efficient, as that of the United States, China's consumption of natural resources, its participation in the international trading and financial systems, its contribution to global technological advance, and its influence in international relations and conflict management are likely to approach and in some cases exceed those of the United States.

The paper is organized as follows. The next section describes the basic model, partly inspired by Edward Denison's work, that we use to organize our analysis of China's catch-up prospects. We next examine the magnitude of the relevant productivity gaps, and we focus on the Chinese 
economy's dynamic catch-up processes for reducing both the international and the internal gaps. We then combine our empirical findings to discuss the prospects and challenges for China's GDP to catch up with that of the United States during the next twenty-five to thirty years. As already suggested, any analysis of China's catch-up prospects over such a horizon must take into account the role of institutions, including both the constraints they set and the opportunities they offer for shaping the pace at which the relevant productivity gaps are reduced. Finally, we focus on the political economy of China's economic growth, and we draw various conclusions from our analysis, including some policy implications.

\section{The Basic Model: Two Productivity Gaps}

In his study of the process by which living standards in the major nonU.S. industrial economies narrowed the gap with, and ultimately caught up to, those in the United States, Denison identified several sources of this catch-up, three of which he viewed as key: resource reallocation, scale economies, and movement toward the international technological frontier (table 1). ${ }^{2}$ In his study of China's long-run performance, Angus Maddison cites these same three sources of long-run growth:

Countries in this situation of relative backwardness and distance from the technological frontier have a capacity for fast growth if they mobilise and allocate physical and human capital effectively, adapt foreign technology to their factor proportions and utilise the opportunities for specialisation which come from integration into the world economy. ${ }^{3}$

A close examination of Denison's results suggests the following lessons:

-Within the current group of advanced industrial countries (members of the Organization for Economic Cooperation and Development, or OECD), labor productivity in the initially poorer countries grew faster than it did in the richer countries-a necessary condition for catch-up.

- Some labor productivity growth originated with capital accumulation (capital deepening), but for the lower-income economies the most important source of catch-up was growth in total factor productivity (TFP).

2. Denison (1967).

3. Maddison (1998, p. 17). 


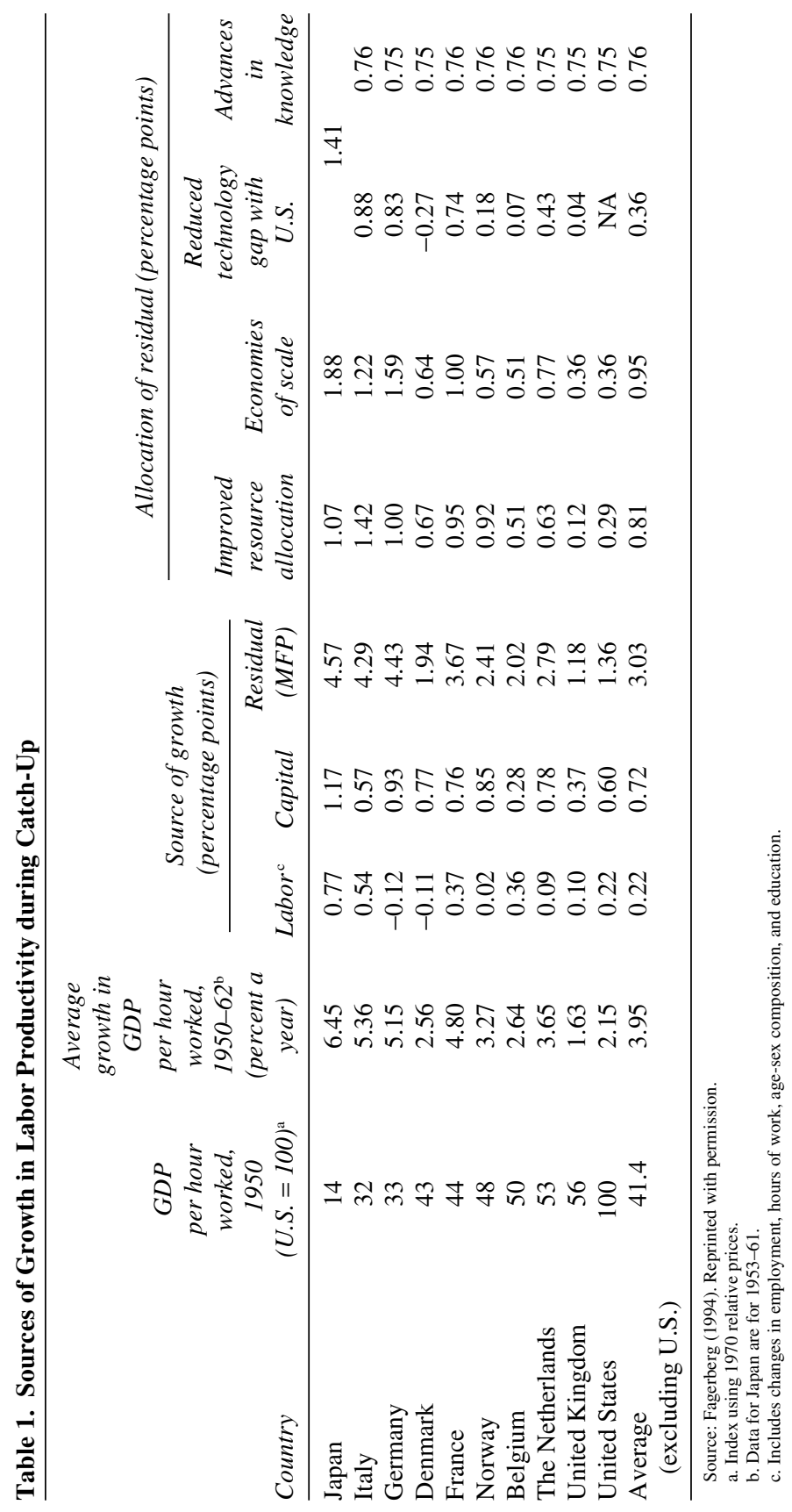


-Among the sources of TFP growth, the creation of scale economies and resource reallocation were most important to the catch-up process. Movement toward the international technology frontier was less important for the group as a whole.

Although, statistically, the results in table 1 confirm the relative unimportance of movement toward the international frontier, arguably it is this factor that drives the other two. That is, without the continuous movement of the advanced industrial sector of a developing economy toward the international frontier, the potential gains from internal resource reallocation will eventually be exhausted. Furthermore, establishing scale economies depends substantially on acquiring state-of-the-art technologies that embody the potential to scale up. The international technology frontier is indeed synonymous with innovations that exploit scale economies.

Drawing on Denison's analytical perspective, one can think of China's growth trajectory as being driven by the ongoing reduction of two productivity gaps. The first is the international productivity gap, which reflects the substantial distance between the international technology frontier and China's technology frontier, which we define as the productivity of Chinese industry or, more specifically, as the productivity of industry in China's leading coastal areas. The second is the internal productivity disparity between China's coastal industrial sector and the country's lagging agricultural and services sectors and between coastal industry and the industrial sectors of China's other regions. Of course, the two gaps are not unrelated. Absent an equivalent increase in the productivity of the lagging sectors, as productivity growth in China's advanced industrial sector reduces the international productivity gap, it simultaneously must increase the internal productivity gap, creating the potential for growth through internal technology diffusion and factor reallocation.

The catch-up of China's advanced industrial sector toward the world frontier is fundamentally driven by technological advance, which in turn is driven by the integration of China's industrial economy with the world economy. This integration has been accelerating, spurred by China's accession to the WTO in 2001, the surge of foreign direct investment (FDI) into China during the past decade, and the rapid intensification of R\&D spending, which facilitates the acquisition and diffusion of technology. Rapid movement of China's industrial economy toward the international frontier has been the driver of China's sustained rapid GDP 
growth. Although labor productivity in China's advanced industrial sector leads that of other regions and other sectors, in 2002 it was still less than one quarter that in the United States. Thus, even if China's entire labor force and capital stock were to be efficiently reallocated and were performing at the current level of the country's advanced industrial sector, China's GDP would still be smaller than U.S. GDP.

However, productivity differences across China's regions and sectors have not diminished during the reform period; indeed, ample evidence suggests that they have widened. China's catch-up thus will require not only the reallocation of labor and capital to the advanced sectors, but also the diffusion of productivity-enhancing technology in the other direction, to the backward sectors. Several institutional reforms will be needed to support the restructuring and upgrading of the backward regions and sectors, including land ownership reform, reductions in impediments to labor mobility and interregional trade, banking and corporate governance reform, and laws governing antitrust, bankruptcy, and mergers and acquisitions. (We examine the functions and political economy of these institutional requirements later in the paper.) If levels of productivity across regions and sectors within China do not converge, China's coastal industry will bear the burden of catch-up, which will make that catch-up more difficult given the tendency for productivity growth in a developing country to slow as its industrial productivity frontier approaches the world productivity frontier.

\section{Measuring the Productivity Gaps: A First Look}

We attempt here to assess the magnitude of China's international and internal productivity gaps. With respect to the latter, we examine in some detail the gaps in labor productivity between industry and agriculture, and between industry and services, both across China and within each of its four major regions. We report findings using both unadjusted employment data from China's National Bureau of Statistics (NBS) and data that correct for a possible overcounting of employment in agriculture and undercounting in the other sectors. Finally, we extend the analysis beyond labor productivity to capital and total factor productivity. 


\section{The International Gap}

Figure 1 illustrates labor productivity differentials for twenty-seven manufacturing industries at the two-digit standard classification level. ${ }^{4}$ The figure shows productivity gaps between China's industries and the international frontier industries, defined as the corresponding industry in the United States or Japan, whichever of the two had the higher labor productivity. ${ }^{5}$ Comparisons are made for 1995 and 2002, for industry in each of China's four major regions: coastal, northeastern, central, and western. ${ }^{6}$ Since the Chinese provincial data are based on a subset of the firm-level data from the large and medium-size enterprise (LME) data set of China's NBS (thus omitting presumably less efficient small firms), we anticipate some upward bias favoring China in these comparisons. On average for the twenty-seven industries, industrial labor productivity in the coastal region in 2002 was just one quarter that of the international frontier. However, this difference represents a substantial gain compared with 1995, when labor productivity at the world frontier was nine times that of the coast. The figure shows that during this seven-year period, within the coastal region, all but four of the twenty-six industries with available data exhibited catch-up. ${ }^{7}$

One industry that stands out in figure 1 is the food, beverage, and tobacco industry (5), where the rate of catch-up in 2002 seems substantially faster than in China's other industries. A key reason for this disparity is the existence of extremely high profits in the tobacco industry: 20.6 percent of total industrial costs in 2002 compared with an overall

4. The industry productivity data for the United States and Japan are from the Groningen Growth and Development Centre, University of Groningen, The Netherlands (www.ggdc.net/ dseries/60-industry.shtml); the industry data for the thirty-one Chinese provinces, autonomous areas, and municipalities are based on firm-level data from the large and medium-size enterprise data set compiled by China's NBS.

5. Among the twenty-seven industries, in 2002 the U.S. industry represented the frontier in seventeen, and the Japanese industry in the remaining ten.

6. The coastal provinces and autonomous municipalities (hereafter referred to simply as "provinces") are Beijing, Fujian, Guangdong, Hainan, Jiangsu, Shandong, Shanghai, Tianjin, and Zhejiang; the northeastern provinces are Heilongjiang, Jilin, and Liaoning; the central provinces are Anhui, Guangxi, Hebei, Henan, Hubei, Hunan, Inner Mongolia, Jiangxi, and Shanxi; and the western provinces are Chongqing, Gansu, Guizhou, Ningxia, Qinghai, Shaanxi, Sichuan, Xinjiang, Xizang, and Yunan.

7. For four of the twenty-seven industries — office machinery (19), insulated wire (20), radio and television receivers (24), and airplanes and spacecraft (29) — data are unavailable for at least one of the four regions. 
Figure 1. Chinese Productivity Relative to Productivity at the International Frontier by Region and Industry, 1995 and 2002 ${ }^{a}$

Percent of frontier productivity

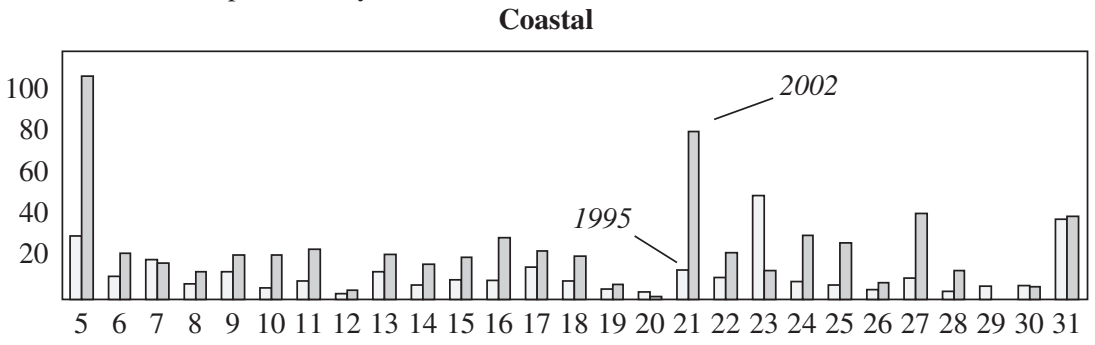

Northeastern

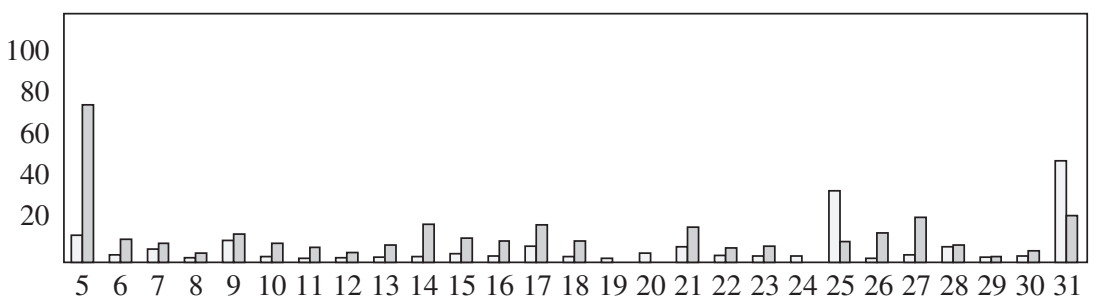

Central

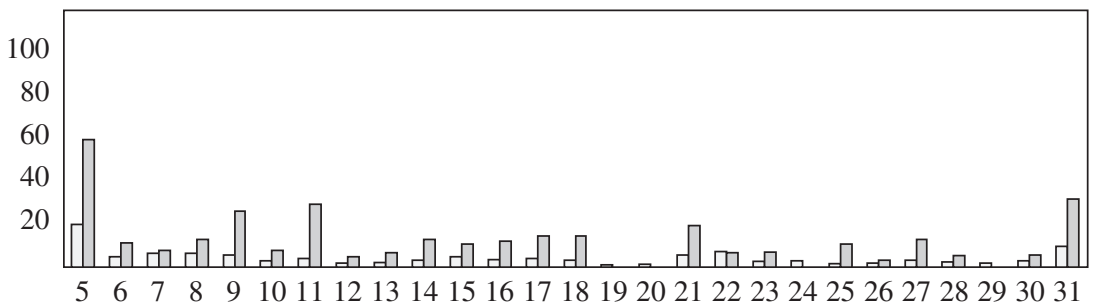

Western

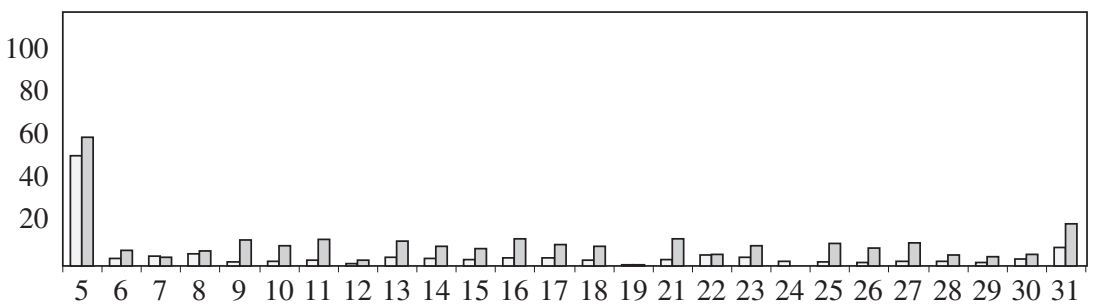

Sources: Groningen Growth and Development Centre, 60-Industry Database, September 2006 (www.ggdc.net); NBS.

a. Firms reporting negative value added are excluded; blank entries indicate missing data.Industry codes are as follows: 5, food, drink, and tobacco; 6, textiles; 7, clothing; 8, leather and footwear; 9, wood and products of wood and cork; 10, pulp, paper, and paper products; 11 , printing and publishing; 12, mineral oil refining, coke, and nuclear fuel; 13, chemicals; 14, rubber and plastics; 15 , nonmetallic mineral products; 16 , base metals; 17 , fabricated metal products; 18 , mechanical engineering; 19 , office machinery; 20, insulated wire; 21 , other electrical machinery and apparatus not elsewhere classified; 22, electronic valves and tubes; 23, telecommunications equipment; 24 , radio and television receivers; 25, scientific instruments; 26 , other instruments; 27 , motor vehicles; 28 , building and repairing of ships and boats; 29 , aircraft and spacecraft; 30 , railroad equipment and transport equipment; 31 , furniture, miscellaneous manufacturing, and recycling. 
Table 2. Industrial Labor Productivity at the International Frontier and in China, 1995 and 2002 ${ }^{\mathrm{a}}$

\begin{tabular}{lcccc}
\hline & \multicolumn{4}{c}{ Region $^{\mathrm{b}}$} \\
\cline { 2 - 5 } Year & Coastal & Northeastern & Central & Western \\
\hline $\begin{array}{l}1995 \\
\begin{array}{l}\text { Ratio of frontier productivity } \\
\text { to productivity in China }\end{array}\end{array}$ & 8.55 & 15.87 & 26.32 & 33.33 \\
$\begin{array}{l}\text { Ratio of coastal productivity } \\
\text { to regional productivity }\end{array}$ & 1.00 & 1.86 & 3.08 & 3.90 \\
$\begin{array}{l}2002 \\
\begin{array}{l}\text { Ratio of frontier productivity } \\
\text { to productivity in China }\end{array}\end{array}$ & 4.31 & 8.93 & 8.00 & 10.87 \\
$\begin{array}{l}\text { Ratio of coastal productivity } \\
\text { to regional productivity }\end{array}$ & 1.00 & 2.07 & 1.86 & 2.52 \\
$\begin{array}{l}\text { Decline in ratio of frontier } \\
\text { productivity to Chinese } \\
\text { productivity, 1995-2002 } \\
\text { (percent) }\end{array}$ & 49.6 & 43.7 & 69.6 & 67.4 \\
\hline
\end{tabular}

Sources: Groningen Growth and Development Centre, 60-Industry Database, September 2006 (www.ggdc.net); National Bureau of Statistics, China; authors' calculations.

a. Data exclude food, beverage, and tobacco industry.

b. Data are aggregations of firm-level data.

industrial profit rate of 5.6 percent. $^{8}$ Also, in that year estimated labor productivity in China's tobacco industry exceeded that for overall industry by nearly a factor of ten. For these reasons, which are likely to result from the government's restrictions on entry to the tobacco industry, we omit the food, beverage, and tobacco industry from our calculations in table 2, which focuses on regional differences in China's manufacturing productivity in relation to the international frontier.

\section{The Internal Gaps}

China's internal productivity gap can be described along two dimensions. The first is the gap between the advanced industrial sector and other, more backward sectors, especially the rural agricultural sector, in which much

8. China Statistical Yearboook 2002, table 14-6. 
of China's labor force resides as underemployed or surplus labor. We also look at productivity gaps between Chinese industry and the Chinese services sector, as well as gaps across regions within the services sector. The second dimension of the internal productivity gap is that within industry across regions, and in particular between the advanced industrial sector, primarily concentrated in parts of China's coastal region, and the relatively backward industries located in the northeastern, central, and western regions. We examine the magnitudes of both types of gaps.

THE AGRICULTURAL-INDUSTRIAL GAP. Table 3 compares average labor productivity (output per worker) in the agricultural sector broadly defined (agriculture, forestry, and fishing) with that in the industrial (including construction) sector. ${ }^{9}$ The last column in the table reports the ratio of the two productivities. The table reveals, first, that the agricultural-industrial productivity gap is large. In 2005 the average industrial worker produced more than seven times as much as his or her agricultural counterpart. Moreover, the gap has grown. From 6.1 in 1980, the ratio of industrial to agricultural productivity had shrunk by 1990 to 4.3, but thereafter it grew continuously until, at 7.1 in 2005, it surpassed the 1980 level.

REGIONAL AND SECTORAL GAPS. The data in table 3 provide a historical perspective on changes in the agricultural-industrial productivity gap, but they do not provide insight into the variety and range of productivity gaps that exist across regions and sectors, including the services sector. To provide this broader picture, table 4 uses official NBS data to compute the gaps for the industry, agriculture, and services sectors across the four regions for 1995 and 2004 . We address both the magnitude of the gaps and whether, during 1995-2004, they have tended to widen or narrow. The table uses productivity in China's coastal industry, which we designate as China's technology frontier, as the point of reference in these comparisons.

We examine first the gaps in 1995. Ratios of productivity in coastal industry to that of industry in the other three regions ranged from 1.78 (western) to 1.32 (northeastern). The largest ratios are those between coastal industry and the agricultural sector, which range from 4.47 (for

9. Of course, for purposes of analyzing patterns of efficient factor allocation, the relevant measure is marginal, not average productivity. We assume that labor's output elasticities in the different sectors are not vastly different from one another. 


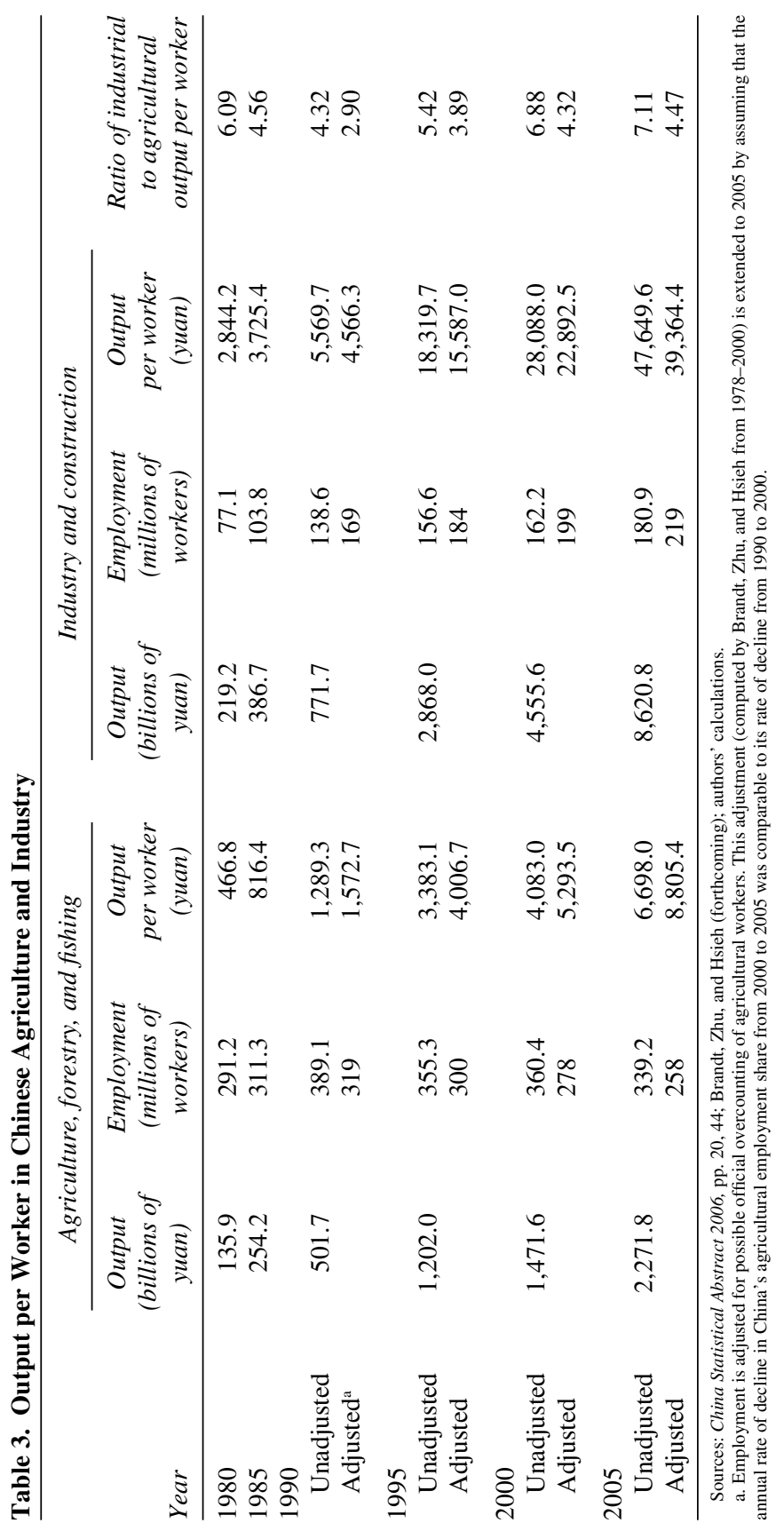




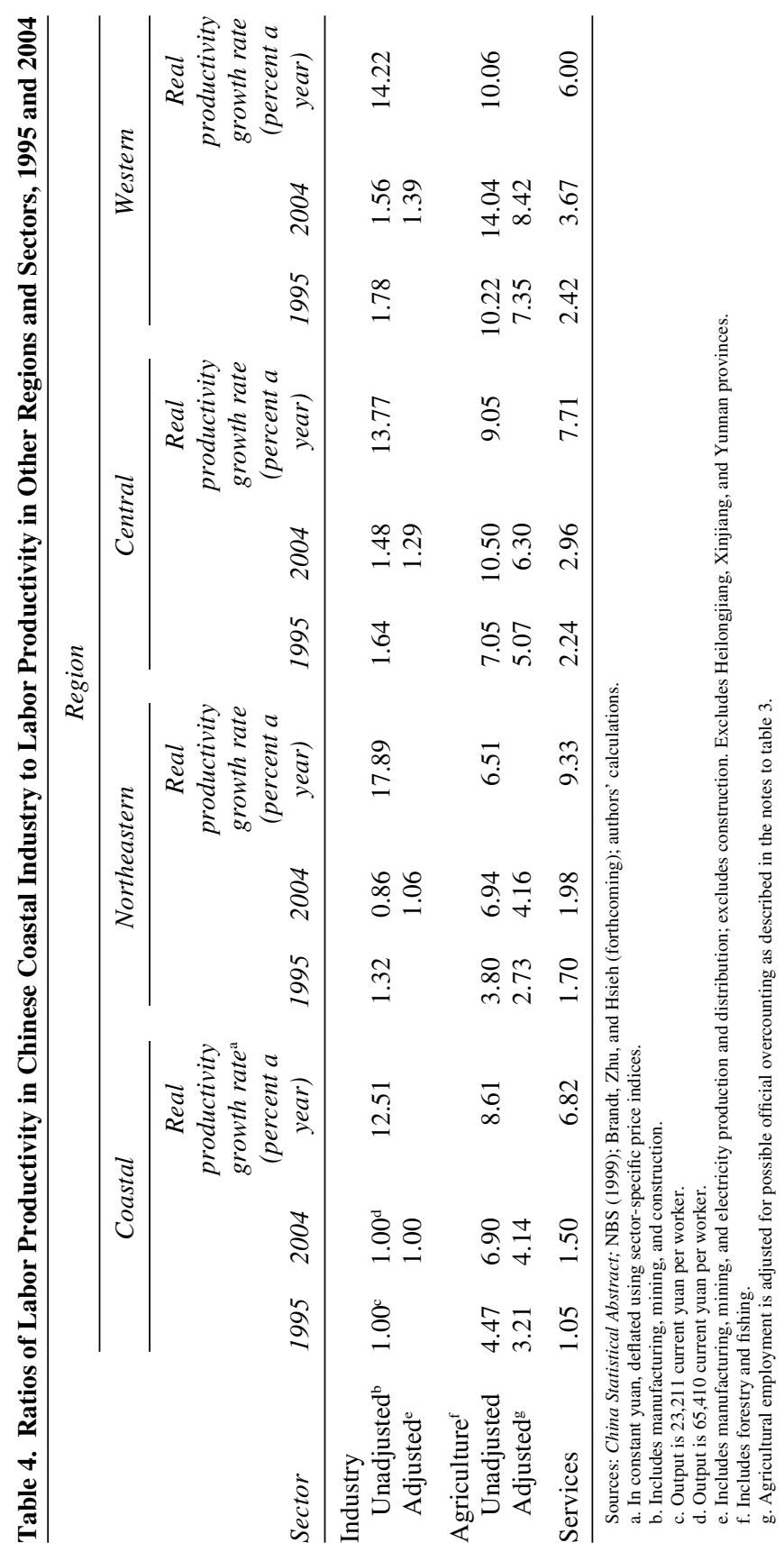


coastal agriculture) to 10.22 (for western). The ratios between coastal industry and the services sector range from 1.05 (coastal) to 2.42 (western). For 2004, table 4 shows a tendency for the industry gaps to shrink, particularly that between the coastal and the northeastern industrial sectors, where industry in the northeastern region appears to have surpassed that of the coast, even as the coastal industry-regional agricultural gaps increased substantially. The gaps between coastal industry and the services sector also tended to increase. Among the eleven pairwise cases, we find a widening of the gap from 1995 to 2004 in all but three. Although some convergence of labor productivity has occurred within industry, the productivity gap between industry and the agricultural and services sectors generally increased during 1995-2004.

MEASUREMENT ISSUES. The disparities between industry and agriculture and between services and agriculture may be somewhat overstated if workers who are temporarily migrating to the cities are included in the agricultural totals. Xiaoquan Ding, and Yang Du and Albert Park, argue that the data in the China Statistical Yearbook overstate the number of workers in agriculture. ${ }^{10}$ According to Ding, "the official statistics on agriculture employment are based on the registered permanent residence system. Although this system impedes rural residents from obtaining urban registration, it cannot prevent rural residents from moving to cities and working in industries." ${ }^{11}$ Ding asserts that many migrant workers living in cities and those working in township and village enterprises are erroneously classified as agriculture workers. Thomas Rawski and Robert Mead estimate that, in the early 1990s, the overcount may have been as high as 100 million, so that 230 million Chinese workers rather than the reported 330 million were actually working in agriculture. ${ }^{12}$

Loren Brandt, Xiaodong Zhu, and Chang-Tai Hsieh construct an alternative series of sectoral employment figures to take this possible miscounting into account. ${ }^{13}$ Their agricultural employment data are constructed by taking the NBS estimate, which is already adjusted for employment in rural township and village enterprises, and further correcting for those working in private firms or self-employed in nonagricultural activities. This correction results in a substantial shift in employment shares: whereas the NBS data

10. Ding (2001); Du and Park (2005).

11. Ding (2001, p. 23).

12. Rawski and Mead (1998).

13. Brandt, Zhu, and Hsieh (forthcoming). 
Figure 2. Share of Agriculture in Employment in China, Other Selected Asian Countries, and the United States, 1948-2004

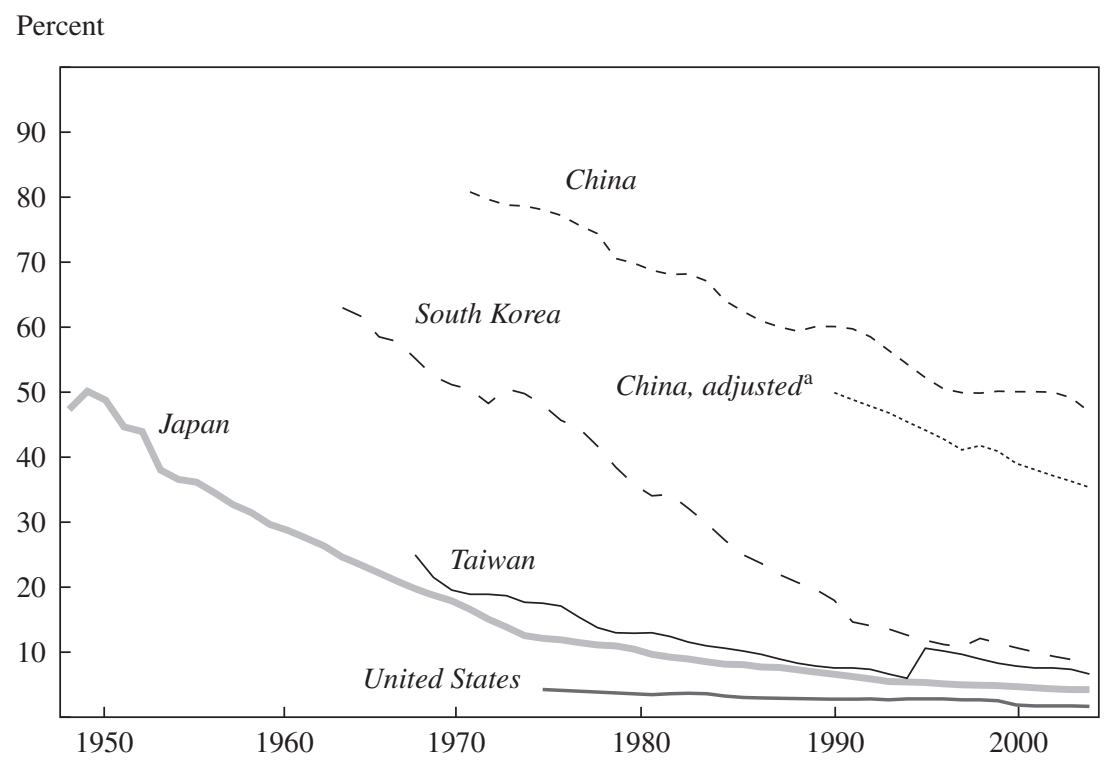

for 1995 indicate that 52.2 percent of China's workforce was employed in agriculture in that year, Brandt, Zhu, and Hsieh's corrected figures set the share at 44.1 percent. The shares of the industrial and services sectors, recorded by the NBS as 23.0 percent and 24.8 percent, respectively, in 1995 rise to 27.1 percent and 28.8 percent under the corrections. The corrections by Brandt, Zhu, and Hsieh end in 2000; we therefore adjust the 2005 NBS figures by assuming that the decline in China's agricultural employment share from 2000 to 2005 proceeds at more or less the same rate as in Brandt's adjusted data for 1990-2000, that is, an annual decrease of 1 percentage point. Thus we assume that China's agricultural employment share in 2005 was 34 percent, which roughly corresponds to that in South Korea in 1982 (figure 2). ${ }^{14}$ To complete the series, we reallocate the agricultural

14. In fact, figure 2, once corrected using Brandt, Zhu, and Hsieh's estimates of China's employment shares, tracks very closely with South Korea's decline over 1962-82 from 63 percent to 39 percent. 
workers who are dropped in 2005 to the industrial and services sectors in the same proportions as the reallocations to these two sectors for 2000.

We first use these corrected agricultural and industry employment figures to adjust the labor productivity calculations shown in table $3 .{ }^{15}$ With the adjusted figures, we find that the ratio of industrial to agricultural labor productivity for 1995 declines from 5.42 to 3.89 ; for 2005 the decline is from 7.11 to 4.47. Although the adjusted figures still show an increase in the industry-agriculture productivity gap from 1995 to 2000, this increase is substantially less than implied by the original NBS data.

We also use these adjusted employment data to correct the pattern of productivity gaps shown in table 4 . Because the employment adjustments by Brandt and coauthors for industry and services are nearly identical for 1995 (1.18 and 1.16, respectively), as are our extensions for 2004 (1.24 and 1.20 , respectively), and because the absence of provincial and regional corrections requires us to assume that the adjustments are uniform over each of the four regions, we do not recompute the ratios for coastal industry to noncoastal industry or for coastal industry to services. We do recompute the ratios for coastal industry to agriculture, which are shown in table 4. Although, as in table 3, the industry-agriculture gaps using the adjusted data grow substantially less than those using the original NBS data, the results do not change our basic conclusion that overall, in relation to coastal industry, the regional and sectoral productivity gaps grew from 1995 to $2004 .^{16}$

GAPS BETWEEN BACKWARD AND ADVANCED INDUSTRY: A CLOSER LOOK. A second measurement issue relates to the measures of regional industrial labor productivity using the data from the China Statistical Yearbook. These data show three provinces with implausibly high or low levels of labor productivity in 2004: at the high end are Heilongjiang at 95,195 yuan per worker and Xinjiang at 102,551 yuan per worker. At the low end, Beijing's labor productivity is 68,126 yuan per worker. To check these productivity data, we use another set of NBS data that has been

15. We further assume that the allocation of excess nonagricultural workers to industry and services is done in accord with the same proportional adjustments made to these sectors in 2000 .

16. These results are consistent with those in Naughton (forthcoming, figure 9-2) that show an upward drift in China's Gini coefficient through the 1980s and 1990s, including a sharp increase for the period 1996-2002. 
compiled for the "above-scale" (guimo yishang) enterprises with annual sales in excess of 5 million yuan. ${ }^{17}$ In addition to focusing on just those enterprises that regularly report to the NBS, a further advantage of these data is that they exclude construction, a component for which the employment classifications are particularly questionable and whose exclusion allows for comparisons using the conventional definition of industry. When we compute the provincial comparisons using these data, we find that the labor productivity measure for Beijing moves into a plausible range, but those for Heilongjiang and Xinjiang remain implausibly high, as does Yunnan's in addition, exceeding industry's average labor productivity by 32,74 , and 50 percent, respectively. Closer inspection of these three provinces shows that each is dominated by either petroleum extraction or the tobacco industry, both of which enjoy extraordinary profits that account for their high value added per worker. ${ }^{18}$ Therefore we drop these three provinces and recalculate the regional labor productivities using only the remaining ones. The productivity gaps for regional industry using these adjusted data are shown in table 4. Unlike the broader industry data, these do not show the northeast surpassing the coast. The adjusted data continue to show the central region lagging further behind the coastal and northeastern regions, and the western region behind all the others.

These adjustments do not make a substantial difference to the measures of agriculture and services productivity in relation to coastal industry shown in table 4. However, we note that the more narrow definition of industry, excluding construction and firms that do not qualify as "above scale," results in significantly higher average productivity for coastal industry $(98,624$ yuan per worker) than for the broad measure of industry $(65,410$ yuan per worker). This disparity not only underscores the tendency of the sectoral productivity gaps to increase when industry is limited to its more formal definition, but also begins to give some indication of the extent of productivity differences within the industrial sector, for example between formal industry and construction and between the "above scale" firms and the smaller industrial enterprises.

17. China Statistical Yearbook 2005, tables 14-2 and 14-5.

18. Specifically, profit per employee in the petroleum extraction industry is 233,633 yuan per employee; for cigarette manufacturing, it is 184,075 per employee, whereas for total (above-scale) industry, the profit rate is 18,597 yuan per employee (China Statistical Yearbook 2005, table 14-3). 
Table 2 also reports regional comparisons for the industrial sector. These measures, too, cover a different set of firms from those in table 4 . The data in table 2 are based on calculations of labor productivity for our sample of large and medium-size enterprises, which is still more limited than the larger population of above-scale firms. ${ }^{19}$ Our subset of this data set also covers manufacturing only (excluding mining and electric power generation) and compares levels for 1995 and 2002, the last year for which data are available in the Groningen data set. A further difference with the industry data in table 4 is that the table 2 data are deflated. ${ }^{20}$

Although these data are thus not directly comparable to those in table 4, they do provide a useful comparison across regions, in particular by omitting the mining and petroleum sectors, which inflate the comprehensive industry productivity measures for the northeastern and western regions. Table 2 shows that the 1995 gaps were large, with ratios of coastal productivity to regional productivity ranging from 3.90 for the western region to 3.08 for the central region and 1.86 for the northeastern region. By 2002, labor productivity in the central and western regions had reduced the gap with the coastal region: the ratios for that year were 1.86 and 2.52 , respectively. In contrast, labor productivity in the northeastern region fell behind that of the coast, with the ratio of productivities rising from 1.86 in 1995 to 2.07 in 2002 . These manufacturing data that exclude construction, mining, and power generation show persistent gaps between coastal manufacturing and that in the other three regions. Although they show a narrowing of the gaps between the central and western regions and the coast, the gaps remain large. Combining our results in table 2 and table 4, we find that when industry is defined broadly to include petroleum extraction, the northeast is catching up with coastal industry. When industry is limited to manufacturing, however, the northeast exhibits limited or no catch-up.

19. In 2005 industry excluding construction accounted for 86.8 percent of value added of total industry (that is, industry including construction, or what NBS calls "secondary industry"). Above-scale enterprises accounted for 87.3 percent and LMEs for 63.8 percent of industry output (excluding construction; China Statistical Yearbook 2005, pp. 52, 489, 512).

20. The regional data are deflated by deflating value added for each of the LMEs using a gross output price deflator constructed from current- and constant-price output deflators reported by each firm. At the provincial level, the firm-level data are aggregated using each firm's share in total provincial value added as the weight. The regional data are a simple average of the data for the included provinces. 
One shortcoming of our productivity comparisons thus far is that they focus exclusively on labor productivity to the exclusion of capital productivity and the broader measure, total factor productivity. To remedy this exclusion, we use our entire NBS large and medium-size enterprise (LME) data set, which includes firm-level data (including manufacturing and mining enterprises), to regress the log values of labor productivity, capital productivity, and TFP on dummy variables for China's major regions with and without two-digit industry dummies. ${ }^{21}$ These industry data include mining and petroleum extraction and power generation.

One immediately apparent result, shown in table 5, which estimates the regional differences, and table 6 , which summarizes these productivity differentials, is that, as in the industry comparisons shown in table 2 and figure 1, in 1995 the coastal region enjoyed a sizable labor productivity advantage over each of the other three regions. The region that diverges most from the coastal region is the northeastern region, followed by the western and central regions. By 2004 all of these disparities had declined substantially.

By contrast, we observe no comparable overall narrowing of the capital productivity gap. In regressions without the industry dummies we observe a consistent increase in the capital productivity gap, as the coast substantially increases its capital efficiency relative to the other three regions. In these estimates, therefore, we find an overall convergence of labor productivity with a simultaneous divergence in capital productivity. In constructing the TFP measures, the larger weight afforded to labor productivity in part accounts for a pattern of overall convergence.

The inclusion of the industry dummies substantially alters the results. For labor productivity, including the industry controls magnifies the productivity disparities in both 1995 and 2004, although their inclusion does not overturn the result of a robust convergence of industrial labor productivity across regions. The industry dummies have the opposite effect on capital productivity, at least in 2004, tending to substantially reduce the productivity gaps between the coast and each of the other three regions, leaving the regional gaps in capital productivity only slightly altered

21. We use a Cobb-Douglas index with weights of 0.64 for labor and 0.36 for capital. These are the values of the output elasticities of labor and capital, respectively, estimated under the restriction of constant returns to scale. 


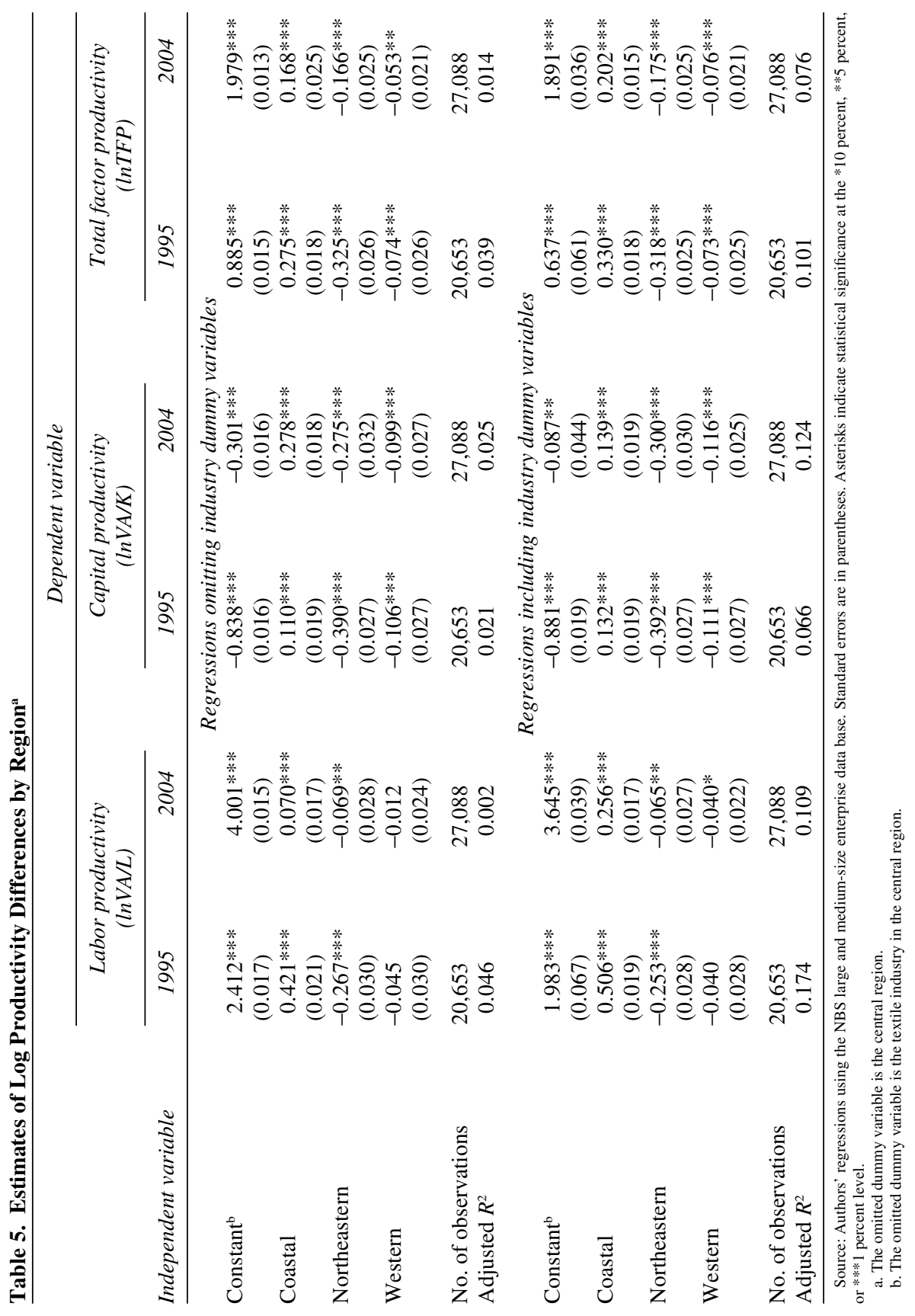


Table 6. Comparisons of Industrial Productivity Estimates by Region

Ratio of coastal productivity to productivity in indicated region

\begin{tabular}{|c|c|c|c|c|}
\hline \multirow[b]{2}{*}{ Dependent variable and region } & \multicolumn{2}{|c|}{$\begin{array}{l}\text { Without industry } \\
\text { dummy variables }\end{array}$} & \multicolumn{2}{|c|}{$\begin{array}{c}\text { With industry } \\
\text { dummy variables }\end{array}$} \\
\hline & 1995 & 2004 & 1995 & 2004 \\
\hline \multicolumn{5}{|l|}{ Labor productivity $(V A / L)$} \\
\hline Coastal & 1.00 & 1.00 & 1.00 & 1.00 \\
\hline Central & 1.52 & 1.07 & 1.66 & 1.29 \\
\hline Northeastern & 1.97 & 1.15 & 2.13 & 1.39 \\
\hline Western & 1.58 & 1.08 & 1.73 & 1.34 \\
\hline \multicolumn{5}{|l|}{ Capital productivity $(V A / K)$} \\
\hline Coastal & 1.00 & 1.00 & 1.00 & 1.00 \\
\hline Central & 1.12 & 1.32 & 1.14 & 1.15 \\
\hline Northeastern & 1.65 & 1.74 & 1.69 & 1.55 \\
\hline Western & 1.24 & 1.47 & 1.23 & 1.29 \\
\hline \multicolumn{5}{|l|}{ Total factor productivity (TFP) } \\
\hline Coastal & 1.00 & 1.00 & 1.00 & 1.00 \\
\hline Central & 1.32 & 1.18 & 1.39 & 1.22 \\
\hline Northeastern & 1.83 & 1.39 & 1.90 & 1.45 \\
\hline Western & 1.42 & 1.24 & 1.49 & 1.31 \\
\hline
\end{tabular}

Source: Authors' calculations using regression results in table 5 .

relative to 1995 . These industry effects largely reflect the high concentration of extractive industries, including petroleum and natural gas extraction and petroleum refining, in the northeastern and western regions. These capital-intensive industries, which exhibit high labor productivity, also exhibit low capital productivity.

This summary of the results reinforces the notion that industrial labor productivity across China's regions is converging but that coastal industry remains some distance ahead of the other regions. Although the results using industry data that include mining and power generation suggest more rapid catch-up than those using manufacturing alone, the inclusion of these capital-intensive industries also follows a pattern in which capital productivity in the three noncoastal regions is falling further behind that of the coast, thereby slowing but not reversing the catch-up of TFP. In the following two sections we investigate the dynamics of productivity catch-up both internationally and within China's industrial sector. 


\section{Chinese Productivity and the International Frontier}

A question that is central to the pace and timing of China's GDP catchup is how productivity growth in Chinese industry responds to the gap between China's productivity and the international productivity frontier. Because many sources of productivity change, including resource shifts across industries and regions within China, are commingled in the aggregate data, we examine the importance of productivity gaps at the industry level. The firm-level data are aggregated to the industry level for each province, distinguishing twenty-seven industries and thirty-one provinces, so that the unit of observation in the regression is the "province-industryyear." We relate the rate of growth between 1995 and 2002 of these province-industry productivity observations to the gap between productivity in that province and industry and productivity at the international frontier in 1995. We estimate the following basic equation:

$$
\text { (1) } \begin{gathered}
{\left[\ln (V A / L)_{i, j, 2002}-\ln (V A / L)_{i, j, 1995}\right]=\alpha_{0}+\alpha_{1} \ln \left(\mathrm{GAP}_{-} \mathrm{FRONT}\right.} \\
+\alpha_{2}\left[\ln (V A / L)_{\mathrm{FRONT}, j, 2002}-\ln (V A / L)_{\mathrm{FRONT}, j, 1995}\right]+\varepsilon,
\end{gathered}
$$

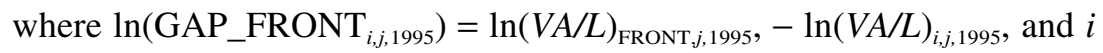
indexes provinces and $j$ industries. (The rates of growth are annualized.) To test for regional differences in the response, we include dummy values of $\alpha_{1}$ for three of the four regions, where the dummy variables interact with the 1995 productivity gaps.

Our priors are that $\alpha_{1}>0$, reflecting the fact that industries and regions that are further behind the international productivity frontier can make bigger gains by exploiting the frontier technology, either by imitation or by importing technology or capital. One might anticipate that the sign on $\alpha_{2}$ would likewise be positive, indicating that the more rapid is productivity growth during 1995-2002 for a frontier industry, the more generally available the useful technology and spillovers are in its lagging Chinese counterpart industry during the same period. Alternatively, China's comparative advantage may be greatest in industries such as textiles, apparel, and footwear, where productivity growth in the advanced industrial economies is slow. In this case such Chinese industries might grow rapidly, moderniz- 
ing in the process, leading to a negative $\alpha_{2}$. Similarly, a negative $\alpha_{2}$ would also arise where productivity changes were exceptionally rapid in the frontier industries, providing little opportunity for Chinese firms to begin to catch up technologically, discouraging modernization. As these considerations suggest, the regression results should be interpreted as casting light only on medium-term responses in China's recent development. They are informative about the path that China is on but cannot be used with confidence to infer conditions well outside the data, such as long-run equilibrium conditions.

The estimation results, shown in table 7 , are robust to alternative specifications and samples, showing that the rate of industrial productivity growth during 1995-2002 rises monotonically with the distance of the relevant industry from the corresponding frontier productivity level in 1995. The quadratic term becomes highly statistically significant when the constant, which itself is generally not highly significant, is constrained to equal zero.

The findings in table 7 are consistent with Denison's finding (table 1) that the rate of labor productivity growth in catch-up countries slows as these countries move toward the international productivity frontier. We further find, as shown by the large coefficient on the variable that interacts China's coastal region dummy with the gap variable, that coastal firms generally enjoy higher rates of productivity growth than do firms in the other three regions for every level of the productivity gap. The results reported for regression 7-5 in table 7 are mapped into figure 3, which shows how productivity growth in both the coastal and other regions relates to an industry's productivity gap, expressed as the ratio of frontier productivity to Chinese productivity in a given industry, assuming a 2 percent annual growth rate of productivity at the frontier. The figure illustrates the potential importance of pure technological catch-up at the firm level. The effects of gaps are highly significant, and the average productivity improvement of coastal industries in the face of international gaps is substantial at the level of the gap observed in most industries in 1995. For example, with a ratio between industry productivities of 10 , which is smaller than that in many industries in that year, the implied rate of labor productivity growth is 11 percent a year in the coastal region, indicating a rapid reduction of such industry gaps even with substantial growth in frontier productivity. The predicted growth in productivity for a comparable gap in other regions is lower but still substantial (roughly 


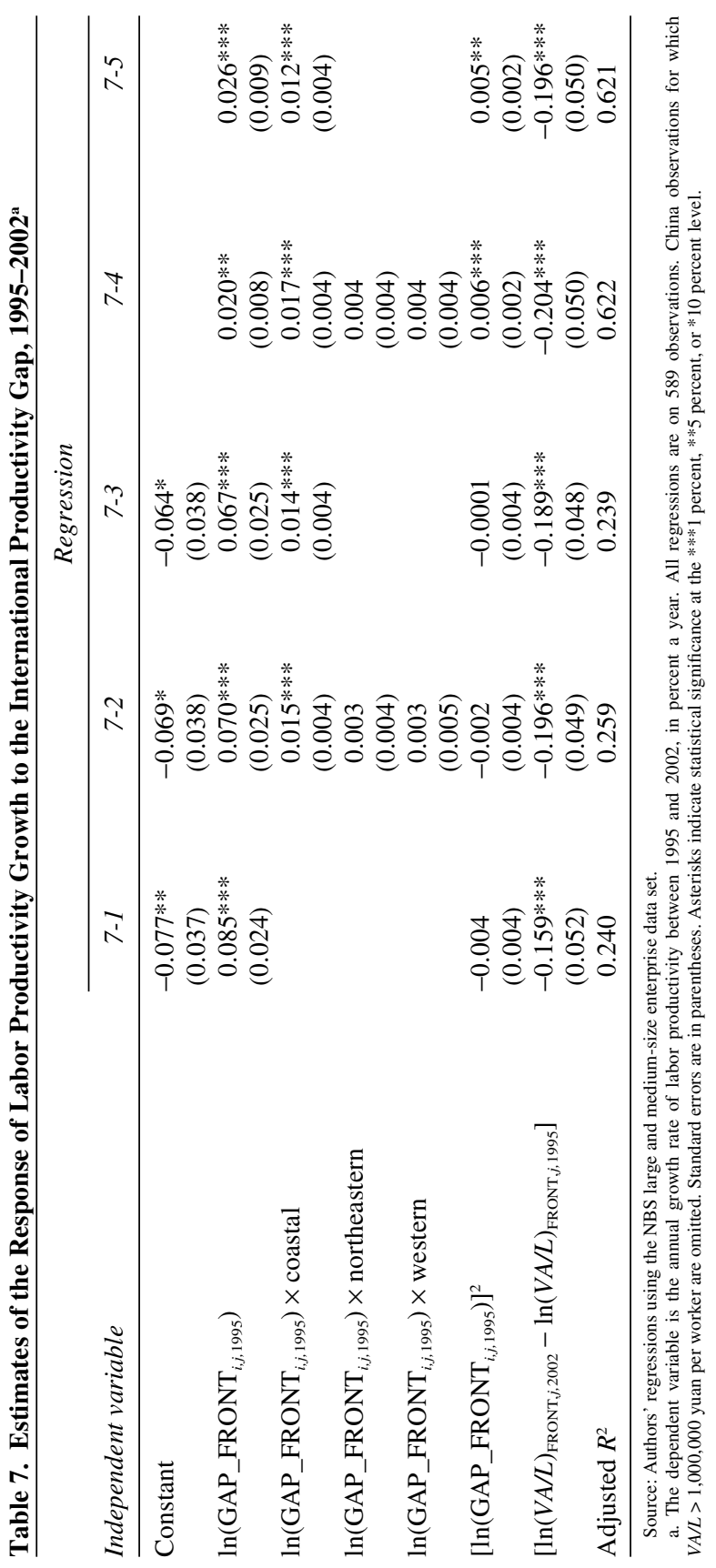


Figure 3. Response of the Chinese Productivity Growth Rate to the Gap with the International Frontier ${ }^{\mathrm{a}}$

Growth rate of Chinese productivity

(percent a year)

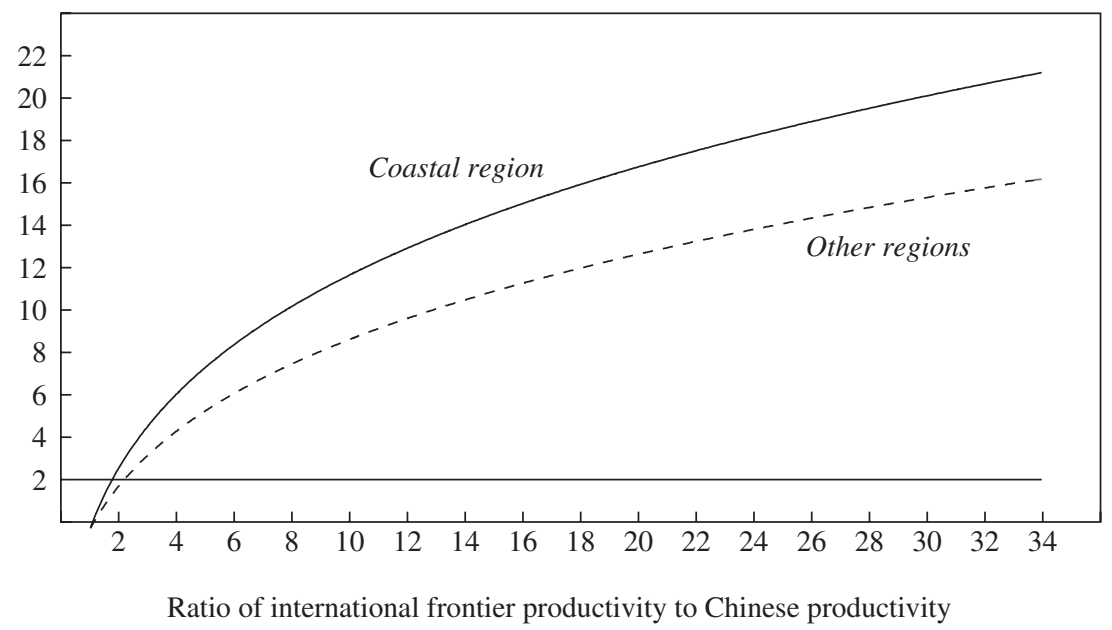

Source: Authors' calculations using regression results in table 7.

a. Calculated assuming a 2 percent productivity growth rate at the international frontier, indicated by the horizontal line.

8 percent). The estimation results shown in table 7 and their illustration in figure 3 also imply that, at least for manufacturing, the northeastern, central, and western regions may enjoy rapid productivity growth but will not fully catch up to the coast, at least in the medium term. As the results show, productivity growth in these regions will grow as fast as that in coastal manufacturing only as long as a substantial productivity gap persists.

Factors that may explain this persistent disparity between the coastal and other regions include the concentration of FDI and R\&D spending in the coastal region and the better development of institutional arrangements, including the legal system and human capital development in the coastal region. Together these factors may enable coastal industry to take greater advantage of international technology than industry in other regions can, even though its gap with the world frontier may be considerably smaller than those of industry in other regions. We return to these issues later in the paper. 


\section{Sources of Internal Productivity Growth}

Our investigation of the responsiveness of labor productivity growth in China's domestic industry to international productivity gaps has shown, with the existing large gap, an initial tendency for sustained labor productivity growth and catch-up, particularly in the coastal region. We also find, in tables 2, 4, 5, and 6, evidence within China's industrial sector of catchup with coastal industry by the other regions, at least for labor productivity and TFP, if not for capital productivity. This part of the paper investigates the processes through which Chinese firms may or may not respond to productivity differentials within Chinese industry by closing the internal productivity gap. The analysis examines the following issues: What are the contributions of labor reallocation and capital accumulation to productivity growth? Can evidence be found of improved allocative efficiency within China's industrial sector, that is, a closing of productivity gaps arising from the reallocation of labor and investment to firms that offer higher returns? And what is the contribution of the exit and entry of firms to industrial productivity growth?

\section{The Contribution of Labor Reallocation}

As reported above, we find large differences in labor productivity among sectors and regions within China. Given these differences, the reallocation of labor from low- to high-productivity sectors or firms could have substantial effects on aggregate output and productivity. To clarify the potential importance of this mechanism for explaining the rapid growth of Chinese output in the last decade and its potential importance for future growth, we consider a two-sector model in which labor productivity in agriculture is designated $P_{a}$ and that in industry $g P_{a}$. Assuming that neither productivity in agriculture nor productivity in industry changes significantly with the reallocation of labor, moving one unit of labor from agriculture to industry increases output by $(g-1) P_{a}$.

Taking the labor force $L_{0}$ as given, with an initial fraction $\beta$ of $L$ employed in agriculture, aggregate output is

$$
Q=\left[\beta P_{a}+(1-\beta) g P_{a}\right] L_{0}=[\beta+(1-\beta) g] P_{a} L_{0} .
$$


Figure 4. Impact of Labor Reallocation on GDP Growth for Alternative Shares of Employment in Low-Income Sectors ${ }^{a}$

Contribution to GDP growth rate (percentage points)

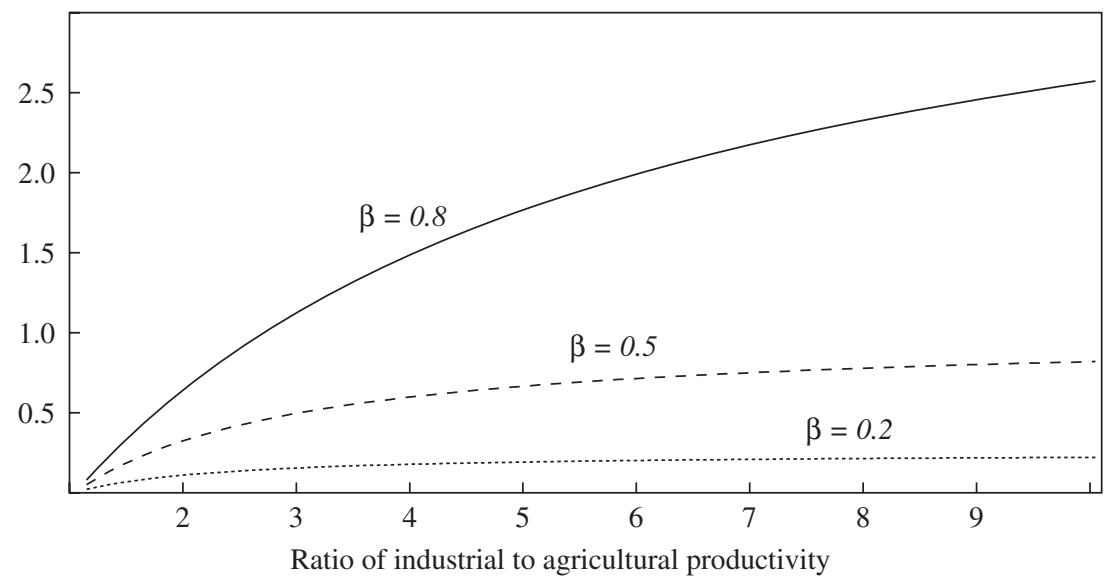

Source: Authors' calculations

a. Assumes that 1 percent of the low-income labor force moves into the high-income sector each year; $\beta$ indicates the initial share of the labor force in the low-income sector.

If labor moves out of agriculture at a rate of $b$ percent a year (that is, the percentage rate of change of $\beta$ is $-b$ ), the percentage rate of change of $Q$ is simply

$$
\frac{\dot{Q}}{Q}=\frac{\beta b(g-1)}{\beta+g(1-\beta)} .
$$

This expression can be used to calculate the growth in total output arising from reallocation across any two sectors whose productivities differ. Note that the crucial parameters for this calculation, $g$ and $\beta$, enter nonlinearly.

Figure 4 shows how the contribution to output growth of annually reallocating 1 percent of the labor in the low-productivity sector to the highproductivity sector varies with $g$. The figure shows this relation for three different values of $\beta$, the initial fraction of labor in the low-productivity sector. Obviously, the larger is $\beta$, the greater is the contribution of reallocating a given percentage of the low-productivity workers. The fact of diminishing 
marginal returns to the size of the gap is not as obvious. The concavity of the response function reflects the fact that, for a given $\beta$ and a given level of productivity in the low-productivity sector, a larger gap implies higher output in the high-productivity sector and a larger overall economy. Although the increase in total output from a reallocation of a unit is proportional to the productivity gap, it represents a smaller percentage of total output.

Figure 4 allows us to examine some of these effects quantitatively. The employment share of China's agricultural sector is currently around 0.4. Assuming a ratio of industrial to agricultural productivity of 5 (roughly the gap shown in table 3 for 1995), our model predicts that a 1 percent annual labor reallocation from agriculture to industry will result in approximately a 0.5-percentage-point contribution to annual GDP growth. Of course, much of China's industrial sector is also backward. As a further illustration, therefore, consider migration from, say, the 80 percent of the labor force that may reside in the aggregate of China's relatively backward agricultural and industrial sectors. Assuming an average productivity ratio of 2.5 for this low-productivity "sector," if 1 percent of its labor migrates each year to the higher-productivity industrial sector, the result, as shown by the upper curve in figure 4, is a 1-percentage-point increase in annual GDP growth. This migration, of course, reduces the employment share of this low-productivity sector. When it is only 50 percent (the middle curve in figure 4), the same 1 percent reallocation, given the same ratio of 2.5 , generates additional GDP growth of less than 0.5 percentage point.

To summarize, two factors lead to a diminishing contribution to GDP growth from labor reallocation. The first of these, particularly with respect to agriculture, is the diminishing number of surplus workers as a share of the total workforce. The second, which acts as a drag on the ability of labor reallocation to sustain rapid GDP growth, is the fact that although widening gaps signal greater productivity gains for each migrating worker, they also imply smaller relative contributions to GDP growth, since increasing productivities in the advanced areas increase GDP. By entering the denominator of the GDP growth calculations, the higher GDP resulting from the larger gaps causes productivity gains from labor reallocations to make smaller proportionate contributions to overall growth.

\section{Evidence of Efficient Reallocation among Industrial Firms}

Differences in productivity across industries and regions can be as large as or larger than the average gap between agriculture and industry dis- 
cussed above. To what extent does it appear that labor and capital have been reallocated from less to more productive industrial firms in China during the last decade? We first examine the behavior of firms in our NBS panel of large and medium-size enterprises that were operating and reporting in 1995, 2000, and 2004, testing to see if a firm's initial factor productivities affect subsequent growth in the firm's labor, capital, and value added. Later we will compare the behavior of these firms with that of firms that exit or enter during the period. We also examine the change in factor productivities themselves. To address these issues, the following equations are estimated for the two periods 1995-2000 and 2000-04:

$$
\begin{gathered}
\ln L_{i, t}-\ln L_{i, t-\tau}=\alpha_{0}+\alpha_{1} \ln M P L_{i, t-\tau} \\
+\sum_{j} \beta_{j}\left(\ln M P L_{i, t-\tau} \times R E G_{j}\right)+\varepsilon \\
\ln K_{i, t}-\ln K_{i, t-\tau}=\beta_{0}+\beta_{1} \ln M P K_{i, t-\tau} \\
+\sum_{j} \beta_{j}\left(\ln M P K_{i, t-\tau} \times R E G_{j}\right)+\varepsilon \\
\ln V A_{i, t}-\ln V A_{i, t-\tau}=\gamma_{0}+\gamma_{1} \ln T F P_{i, t-\tau} \\
+\sum_{j} \gamma_{j}\left(\ln T F P_{i, t-\tau} \times R E G_{j}\right)+\varepsilon \\
\ln T F P_{i, t}-\ln T F P_{i, t-\tau}=\delta_{0}+\delta_{1} \ln T F P_{i, t-\tau} \\
+\sum_{j} \delta_{j}\left(\ln T F P_{i, t-\tau} \times R E G_{j}\right)+\varepsilon,
\end{gathered}
$$

where $T F P_{i, t}=(V A / K)_{i, t}^{\alpha}(V A / L)_{i, t}^{1-\alpha}$ and $M P L$ and $M P K$ are the marginal products of labor and capital, respectively, and rates of growth are annualized. The inclusion of the interaction terms allows us to test the differences in adjustment dynamics across regions. $\left(R E G_{j}\right.$ is a dummy variable taking on the value 1 for a firm in region $j$ and zero otherwise, with the central region as the omitted region.)

The results in table 8 show that, in both 1995-2000 and 2000-04, changes in the employment of labor and capital across industrial firms were positively related to the firms' initial levels of labor and capital productivity, respectively. For example, in 2000-04, doubling $M P L$ adds about 10 percentage points to the annual growth rate of labor in the central region. Except in the coastal region, growth of labor was more responsive 
Table 8. Reallocation of Labor, Capital, and Output across Industrial Firms, 1995-2000 and 2000-04

\begin{tabular}{|c|c|c|}
\hline Independent variable & $1995-2000$ & $2000-04$ \\
\hline \multicolumn{3}{|c|}{ Dependent variable: annual growth rate of employment } \\
\hline Constant & $\begin{array}{l}-0.431 * * * \\
(0.027)\end{array}$ & $\begin{array}{c}-0.610 * * * \\
(0.031)\end{array}$ \\
\hline $\ln M P L_{i, t-\tau}$ & $\begin{array}{l}0.125^{* * * *} \\
(0.010)\end{array}$ & $\begin{array}{l}0.145^{* * *} \\
(0.010)\end{array}$ \\
\hline $\ln M P L_{i, t-\tau} \times$ coastal & $\begin{array}{c}-0.004 \\
(0.007)\end{array}$ & $\begin{array}{l}-0.020 * * * \\
(0.006)\end{array}$ \\
\hline $\ln M P L_{i, t-\tau} \times$ northeastern & $\begin{array}{c}-0.022 * * \\
(0.011)\end{array}$ & $\begin{array}{l}0.027 * * * \\
(0.010)\end{array}$ \\
\hline $\ln M P L_{i, t-\tau} \times$ western & $\begin{array}{l}-0.030 \\
(0.010) * * *\end{array}$ & $\begin{array}{c}0.017 * \\
(0.009)\end{array}$ \\
\hline No. of observations & 2,639 & 2,684 \\
\hline Adjusted $R^{2}$ & 0.081 & 0.082 \\
\hline \multicolumn{3}{|c|}{ Dependent variable: annual growth rate of the capital stock } \\
\hline Constant & $\begin{array}{l}0.630 * * * \\
(0.015)\end{array}$ & $\begin{array}{l}0.194 * * * \\
(0.027)\end{array}$ \\
\hline $\ln M P K_{i, t-\tau}$ & $\begin{array}{l}0.177 * * * \\
(0.028)\end{array}$ & $\begin{array}{l}0.134 * * * \\
(0.024)\end{array}$ \\
\hline $\ln M P K_{i, t-\tau} \times$ coastal & $\begin{array}{c}-0.017 \\
(0.031)\end{array}$ & $\begin{array}{c}0.007 \\
(0.026)\end{array}$ \\
\hline $\ln M P K_{i, t-\tau} \times$ northeastern & $\begin{array}{c}0.042 \\
(0.040)\end{array}$ & $\begin{array}{c}-0.000 \\
(0.036)\end{array}$ \\
\hline $\ln M P K_{i, t-\tau} \times$ western & $\begin{array}{c}0.059 \\
(0.039)\end{array}$ & $\begin{array}{c}-0.004 \\
(0.032)\end{array}$ \\
\hline No. of observations & 2,639 & 2,684 \\
\hline Adjusted $R^{2}$ & 0.057 & 0.042 \\
\hline \multicolumn{3}{|c|}{ Dependent variable: annual growth rate of value added } \\
\hline Constant & $\begin{array}{l}0.865^{* * *} \\
(0.031)\end{array}$ & $\begin{array}{l}0.801 * * * \\
(0.035)\end{array}$ \\
\hline $\ln T F P_{i, t-\tau}$ & $\begin{array}{c}-0.436 * * * \\
(0.031)\end{array}$ & $\begin{array}{l}-0.323 * * * \\
(0.031)\end{array}$ \\
\hline $\ln T F P_{i, t-\tau} \times$ coastal & $\begin{array}{l}0.111^{* * *} \\
(0.028)\end{array}$ & $\begin{array}{c}0.018 \\
(0.028)\end{array}$ \\
\hline $\ln T F P_{i, t-\tau} \times$ northeastern & $\begin{array}{c}-0.063 \\
(0.048)\end{array}$ & $\begin{array}{c}-0.096^{* *} \\
(0.047)\end{array}$ \\
\hline $\ln T F P_{i, t-\tau} \times$ western & $\begin{array}{c}-0.064 \\
(0.040)\end{array}$ & $\begin{array}{c}-0.022 \\
(0.039)\end{array}$ \\
\hline No. of observations & 2,604 & 2,633 \\
\hline Adjusted $R^{2}$ & 0.134 & $\begin{array}{c}0.088 \\
\text { (continued) }\end{array}$ \\
\hline
\end{tabular}


Table 8. Reallocation of Labor, Capital, and Output across Industrial Firms, 1995-2000 and 2000-04a (Continued)

\begin{tabular}{lcc}
\hline Independent variable & $1995-2000$ & $2000-04$ \\
\hline & Dependent variable: & annual growth rate of TFP \\
Constant & $0.954^{* * *}$ & \\
& $(0.031)$ & $1.003^{* * *}$ \\
$\ln T F P_{i, t-\tau}$ & $-0.555^{* * *}$ & $(0.030)$ \\
& $(0.027)$ & $-0.467 * * *$ \\
$\ln T F P_{i, t-\tau} \times$ coastal & $0.119^{* * *}$ & $(0.027)$ \\
& $(0.024)$ & $0.058^{* *}$ \\
$\ln T F P_{i, t-\tau} \times$ northeastern & 0.008 & $(0.024)$ \\
& $(0.041)$ & -0.049 \\
$\ln T F P_{i, t-\tau} \times$ western & -0.014 & $(0.041)$ \\
& $(0.035)$ & 0.009 \\
No. of observations & 2,604 & $(0.034)$ \\
Adjusted $R^{2}$ & 0.241 & 2,633 \\
\hline Source: Authors' regressions using the NBS large and medium-size enterprise data set. & 0.186 \\
a. Standard errors are in parentheses. Asterisks indicate statistical significance at the ***1 percent, **5 percent, or * 10 percent level.
\end{tabular}

in this later period than in 1995-2000. The increase in the northeast may reflect the extensive layoffs associated with sanctioned furloughs (xiagang) at state-owned enterprises, which were relatively concentrated in that region. The responsiveness of capital formation is similar to that of labor growth, with roughly the same elasticity of growth with respect to its own initial productivity. However, in all regions capital was somewhat more responsive in the earlier than in the later period. Although factor productivities thus play an important role in the allocation of labor and capital, they explain only a small fraction of the variation in labor and capital growth across firms.

The results for the value-added equation (equation 5) are somewhat surprising. Higher total factor productivity in the initial year (1995 or 2000) slows the growth of value added. This result seems paradoxical since, having determined that high initial levels of factor productivity motivate the accumulation of labor and capital, one might have anticipated that high TFP would also lead to relatively rapid growth of value added. If, in fact, growth of value added tends to be slower among firms with high initial levels of TFP, this implies that the higher rates of growth of inputs of labor and capital are associated with substantially slower TFP growth. Such a relationship would be consistent with the idea that low-productivity firms were catching up with high-productivity firms in this period.

This productivity catch-up hypothesis is supported by the regressions in the last panel of table 8 , which show that firms with low initial TFP 
exhibit faster growth of TFP. This catch-up is likely to reflect a diffusion of technology within China's industrial system, as less productive firms access technologies that enable them to move toward industry's technology frontier. Our results also show that the coastal region exhibits less of a tendency for TFP to converge than do the other regions of China. During 2000-04, productivity catch-up is somewhat more pronounced in both the northeastern and coastal regions than it was in the earlier period.

One possible interpretation of the relative lack of catch-up in the coastal area is that that region serves as a cauldron of technology development, where the country's largest R\&D performers and exporters can extend their technological advantages. (In 2004 thirty of the fifty firms with the largest $R \& D$ expenditure were located in the coastal provinces.) The overall impression conveyed by table 8 is that China's industrial economy exhibits attributes of efficient reallocation that bode well for the ability of firms with lagging productivity to access the technologies and organizational changes needed to capture some of the productivity advantages of the more efficient firms. The results also show a degree of factor mobility, enabling resources to move to higher-productivity uses within China's industrial system. These dynamics represent an important engine for sustaining productivity growth outside coastal industry and for further reducing the productivity gap within China's domestic industrial economy.

Although these dynamic adjustment processes probably account for some of the interregional industrial productivity catch-up observed during 1995-2002 (table 2) and 1995-2004 (tables 4 and 6), we emphasize that this catch-up remains partial and uneven. Moreover, our results in table 7 and figure 3 strongly imply the existence of structural limits to full catchup of manufacturing productivity in the northeastern, central, and western regions to that of the coast.

\section{The Contribution of Exit and Entry}

The most important shortcoming of the above analysis of resource allocation and productivity convergence within China's industrial system is that it is limited to firms that survived over the entire period 1995-2004. Firms omitted from the balanced sample include many firms that entered or exited during the period, as well as restructured firms whose identity changed with restructuring, making it impossible to track them separately 
Table 9. Estimates of Productivity Differentials between Survivor Firms, Exiting Firms, and Entrants ${ }^{\mathrm{a}}$

\begin{tabular}{|c|c|c|c|}
\hline \multirow[b]{2}{*}{ Independent variable } & \multicolumn{3}{|c|}{ Dependent variable } \\
\hline & $\begin{array}{c}\text { Labor } \\
\text { productivity } \\
(V A / L)\end{array}$ & $\begin{array}{c}\text { Capital } \\
\text { productivity } \\
(V A / K)\end{array}$ & $\begin{array}{l}\text { Total factor } \\
\text { productivity }\end{array}$ \\
\hline Constant & $\begin{array}{l}57.694 * * * \\
(0.522)\end{array}$ & $\begin{array}{l}1.150 * * * \\
(0.080)\end{array}$ & $\begin{array}{l}12.124 * * * \\
(0.092)\end{array}$ \\
\hline Survivors, 1996-98 & $\begin{array}{l}-6.343 * * * \\
(1.086)\end{array}$ & $\begin{array}{c}-0.409 * * \\
(0.166)\end{array}$ & $\begin{array}{l}-1.590 * * * \\
(0.113)\end{array}$ \\
\hline Survivors, 1999-2001 & $\begin{array}{l}4.667 * * * \\
(1.080)\end{array}$ & $\begin{array}{l}-0.433 * * * \\
(0.165)\end{array}$ & $\begin{array}{c}0.112 \\
(0.190)\end{array}$ \\
\hline Survivors, 2002-04 & $\begin{array}{l}18.937 * * * \\
(1.270)\end{array}$ & $\begin{array}{c}-0.285 \\
(0.194)\end{array}$ & $\begin{array}{l}2.624 * * * \\
(0.224)\end{array}$ \\
\hline Exits, 1996-98 & $\begin{array}{c}-24.537 * * * \\
(0.911)\end{array}$ & $\begin{array}{l}-0.411 * * * \\
(0.139)\end{array}$ & $\begin{array}{l}-4.469 * * * \\
(0.161)\end{array}$ \\
\hline Exits, 1999-2001 & $\begin{array}{c}-30.899 * * * \\
(0.596)\end{array}$ & $\begin{array}{l}-0.291 * * * \\
(0.091)\end{array}$ & $\begin{array}{l}-5.687 * * * \\
(0.105)\end{array}$ \\
\hline Exits, 2002-04 & $\begin{array}{c}-16.733 * * * \\
(0.513)\end{array}$ & $\begin{array}{l}-0.271 * * * \\
(0.078)\end{array}$ & $\begin{array}{l}-3.568 * * * \\
(0.090)\end{array}$ \\
\hline Entrants, 1996-98 & $\begin{array}{l}12.149 * * * \\
(0.564)\end{array}$ & $\begin{array}{c}0.046 \\
(0.086)\end{array}$ & $\begin{array}{l}1.851 \text { *** } \\
(0.099)\end{array}$ \\
\hline Entrants, 1999-2001 & $\begin{array}{l}30.155 * * * \\
(0.572)\end{array}$ & $\begin{array}{l}0.661 * * * \\
(0.087)\end{array}$ & $\begin{array}{l}5.229 * * * \\
(0.101)\end{array}$ \\
\hline Entrants, 2002-04 & $\begin{array}{l}16.232 * * * \\
(0.598)\end{array}$ & $\begin{array}{l}1.197 * * * \\
(0.091)\end{array}$ & $\begin{array}{l}5.460 * * * \\
(0.105)\end{array}$ \\
\hline Adjusted $R^{2}$ & 0.043 & 0.002 & 0.057 \\
\hline
\end{tabular}

from exiting and entering firms. Together these processes of exit, entry, and restructuring are likely to have been an important element in improving productivity. We therefore extend the analysis to account for their impact.

Table 9 uses the full sample of firms over 1995-2004 to estimate the productivity differentials among three categories of firms: firms that survive in the LME data over the entire period 1995-2004 (that is, the firms included in the table 8 regressions), firms that exited from the data set, and firms that entered it. Separate dummy variables for the three types of firms are used for each of the three-year periods: 1996-98, 1999-2001, and 2002-04. We estimate differences among these firm categories for labor, 
capital, and total factor productivity. The results for labor productivity show a distinct pattern in which, relative to the survivors in 1996-98, the exiting firms exhibit low productivity, whereas the entrants exhibit high productivity. During 1996-98 the labor productivity of exiting firms was 35 percent lower, and that of entering firms 36 percent higher, than that of the survivors in the same period. In the following three-year period, the corresponding numbers are 57 percent and 41 percent. Finally, in 2002-04 the labor productivity of exiting firms was 47 percent lower than that of survivors, but entrants were marginally less productive than the survivors.

The importance of exit, entry, and restructuring to overall productivity depends on how frequently they take place. Our data show a high incidence of both exit and entry: nearly 146,000 firms either entered or exited the sample over the nine-year period, drawn from an annual population of 22,000 to 27,000 firms. The large numbers of both exiting and entering firms (roughly as many exited as entered), together with the significant differences between their average productivity and that of surviving firms, suggest that they are indeed an important source of China's industrial productivity growth, but without knowing the size of the firms involved, we cannot precisely measure their contribution.

We have not measured changes in capital productivity in China over the past decade in relation to the international technology frontier in a manner similar to our analysis of labor productivity in table 2 . Based on data from the NBS-LME data set, figure 5 shows that, after bottoming out in 1998, capital productivity began to rise monotonically through 2005. This rise is consistent with our findings that firms with high capital productivity tend to capture new investment and that the exit-entry phenomenon contributes substantially to improvements in capital productivity. The correspondence between the path of capital productivity shown in table 5 and the returns to capital productivity from exit and entry is notable. As table 9 shows, the increase in capital productivity associated with new entry was insignificant during 1996-98 but turned highly significant during 1999-2001 and became still more robust during 2002-04.22

Although the incidence of exit and entry shows no sign of having abated during our ten-year sample, we do see a decline in the resulting productivity gain, at least for labor. The exiting firms in 2002-04 were not

22. Jefferson and $\mathrm{Su}$ (2006) also find that restructuring (that is, conversions of stateowned enterprises into shareholding enterprises) results in higher capital productivity. 
Figure 5. Marginal Product of Capital in China, 1995-2005

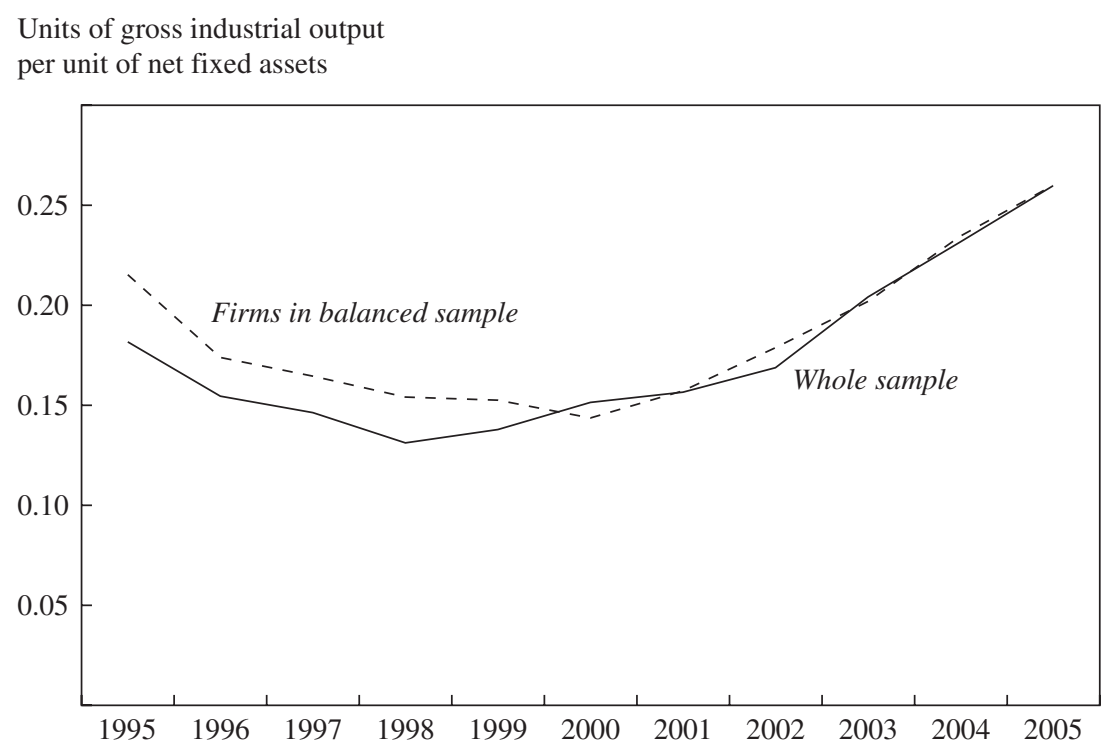

Source: Authors' calculations using NBS data.

as unproductive as those that exited during the previous three-year period, and, unlike the entrants during 1996-2001, which were significantly more productive on average than their survivor counterparts, the entrants during 2002-04 were only about as productive as their cohort survivor group. This result suggests that, assuming some observed entry and exit is due to enterprise restructuring, either the firms for which the most value added could be captured tended to be restructured early, or, where there were multiple restructurings, that they were subject to diminishing returns. We anticipate that, over time, enterprise restructuring in China's industrial sector will make smaller contributions to overall productivity growth.

To summarize, we have analyzed two major sources of catch-up in China's economy. These are increased allocative efficiency, based on the reallocation of capital and labor to the more productive firms and sectors and the diffusion of technology to the relatively backward firms to enable their productivity catch-up; and exit and entry, which we suggest is likely in part to be associated with enterprise restructuring. Although each of these is an important source of productivity growth, 
capable of narrowing the productivity gap between China's relatively backward regions and sectors and its more advanced ones, the contribution of each to continuing productivity growth and GDP growth is likely to diminish over time.

\section{How Sustainable Is China's International Catch-Up?}

Whether China, and in particular its coastal industry, can continue to close the gap with the advanced economies depends broadly on two factors. The first is China's ability to sustain and expand its capacity both to create and absorb new domestic technology and to absorb imported technology. The second factor, on which the first substantially depends, is China's ability, through the functioning of its political economy, to sustain momentum for the underlying institutional reforms that shape the incentives to develop and employ new technologies, accumulate capital, and reallocate labor. Here we discuss the capacity for sustained economic growth through technology development. The next section focuses on the political economy and institutional underpinnings of China's economic growth.

The international productivity gap analysis reported in table 7 and depicted in figure 3 strongly suggests that China's coastal industrial economy can sustain high rates of productivity growth as it reduces its technology gap with the international frontier. A central theme of the endogenous growth literature, however, is that productivity growth is not sustained by manna from heaven; rather, it is the result of deliberate investment in technological opportunity that promises competitive risk-adjusted economic returns.

Here we investigate the sources and measures of technology development that are responsible for driving the technological advance of Chinese industry, particularly in the coastal region. Specifically, we examine the proposition that China has begun its science and technology (S\&T) takeoff, as measured both by a rapid rise in R\&D spending as a share of GDP and by a surge in patenting activity; we argue that, from a comparative and historical perspective, this takeoff is not likely to be reversed.

\section{China's Science and Technology Takeoff}

The historical relationship between R\&D spending and GDP in developing countries shows a striking pattern: as a country's R\&D spending 
Figure 6. Research and Development Spending in Five Countries, 1950-2004

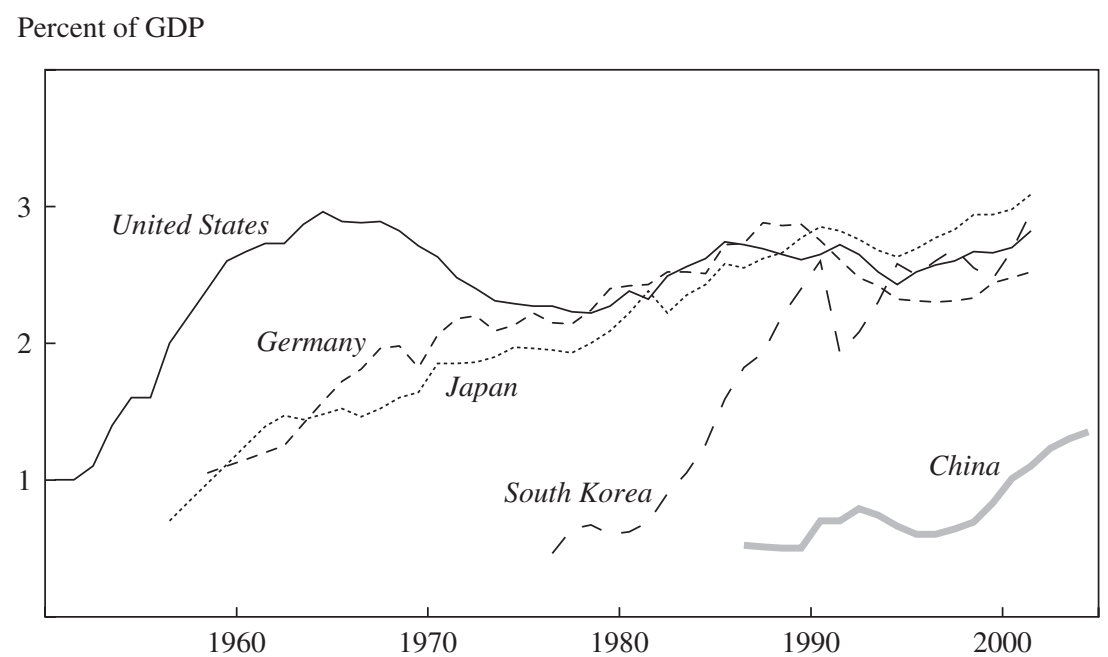

Source: Adapted from Gao and Jefferson (forthcoming).

approaches 1 percent of GDP, it typically then accelerates abruptly, rising to the vicinity of 2 percent, and finally levels off in the range of 2 to 3 percent of GDP. This pattern is particularly robust for countries with large populations, and on average it takes place over the course of a single decade. Jian Gao and Jefferson characterize this phenomenon of an abrupt one-time increase in R\&D intensity as the "science and technology takeoff." ${ }^{23}$ They identify the statistical regularities of such takeoffs and the underlying theoretical and empirical conditions that might explain them.

Figure 6 shows the pattern of R\&D takeoff for five countries. The three large OECD economies in the sample show a similar pattern of S\&T takeoff. In each of these countries, when the ratio of R\&D spending to GDP breached the 1 percent threshold, $R \& D$ spending continued to outpace GDP growth until R\&D intensity stabilized in the range of 2 to 3 percent of GDP. The transition period lasted about ten years on average, ranging from about five years in the case of South Korea to about twenty years for Japan.

23. Gao and Jefferson (forthcoming). 
Drawing on Charles Jones' modeling of endogenous $\mathrm{R} \& \mathrm{D},{ }^{24} \mathrm{Gao}$ and Jefferson identify four factors that, they argue, are now driving China's S\&T takeoff. Briefly, these are a transition from the consumption of final goods that are low in technology content to goods high in technology content; the accumulation of complements to $R \& D$, including investments in information technology and human capital; access to the world's knowledge base and expansion of technological opportunity through international trade and FDI; and exploitation of the wage-productivity gap, including the tendency for compensation of home-country R\&D personnel to lag behind that of their OECD counterparts.

This phenomenon of $R \& D$ intensification is found most consistently in more populous countries, perhaps because their size allows for the creation of scale economies across a broad set of industries. In China the lure of FDI to exploit the potential of the country's domestic markets, as well as its comparatively high levels of basic education and literacy, may also be factors. ${ }^{25}$

Figure 6 shows that China, having achieved a ratio of $R \& D$ spending to GDP of 1.4 percent in 2005, is firmly engaged in its S\&T takeoff. This rapid expansion of $R \& D$ spending has established an important channel through which China's industrial enterprises are able to imitate, adapt, and improve on foreign technologies. China's S\&T takeoff, which represents growing capabilities of Chinese organizations to innovate and imitate, is arguably the critical mechanism for sustaining China's catch-up. Our historical and comparative perspective indicates that this catch-up is likely to be sustainable, as it was for the larger established OECD economies and for the now-high-income East Asian economies. If China follows the path of East Asia's recently industrialized economies-including South Korea, Taiwan, and Singapore, all of which have completed their S\&T takeoffsas well as the larger OECD economies, the intensity of China's R\&D

24. Jones (1995).

25. The factors that drive the $S \& T$ takeoff are also those that account for the leveling off of R\&D intensity, that is, the tendency for the advanced economies to share a similar set of conditions: similar levels of technology intensity in consumption and production, the creation of similar sets of physical infrastructure and human capital complements to $R \& D$ labor, a more or less identical international technology frontier, and comparable wages for R\&D personnel. The equalization of these four factors across the advanced economies causes their R\&D intensities to converge within a narrow range, thus bringing an end to the S\&T takeoff. 
Figure 7. Patent Applications in China, 1986-2004

Thousands Thousands

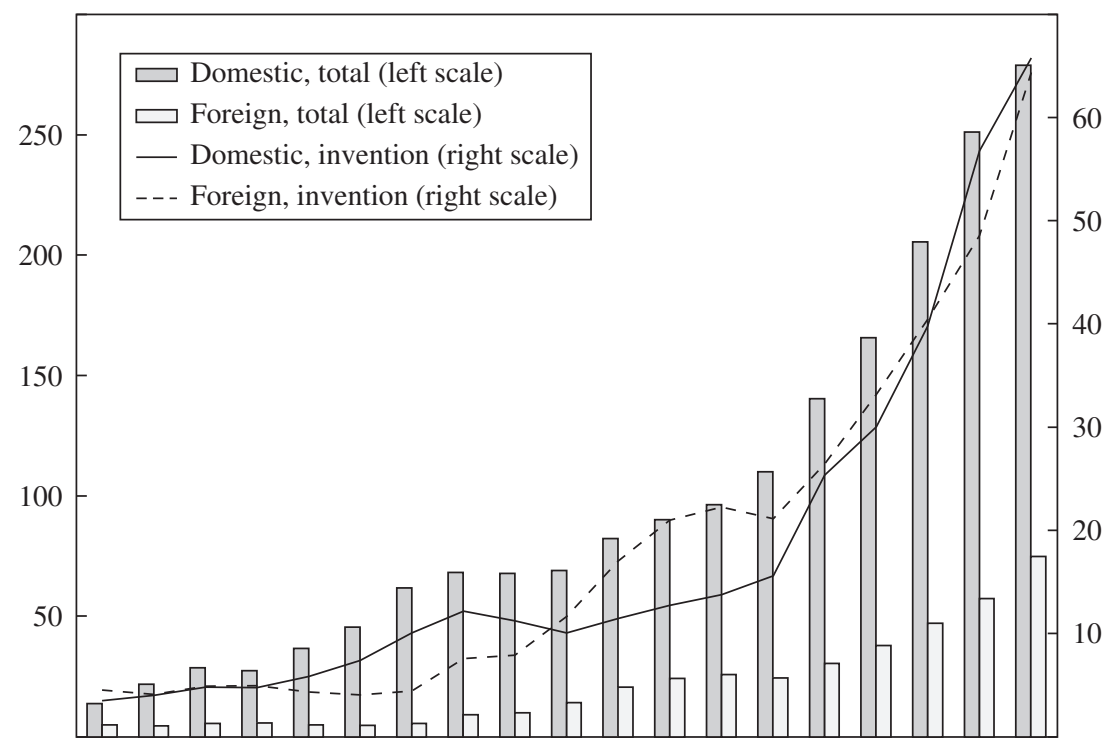

1986198719881989199019911992199319941995199619971998199920002001200220032004

effort, if not yet its quality, is likely to approach that of the major advanced economies sometime during the next decade.

\section{Patenting}

Figure 7 shows the surge in patenting in China that began in 1999, in part reflecting the implementation of several key patent law changes in anticipation of China's accession to the Agreement on Trade-Related Aspects of Intellectual Property Rights (TRIPS) of the WTO. Hu and Jefferson show that a critical driver of the patenting surge has been FDI. ${ }^{26}$ Firms, especially domestic firms, that were particularly patent intensive were typically located in those three-digit industries that exhibited the highest FDI concentrations. This association suggests that the technology transfer

26. Hu and Jefferson (2006). 
associated with FDI opened up new technological opportunities for imitation. Domestic firms accounted for 60,000 to 70,000 invention patents in 2004 and for virtually all of the approximately 220,000 utility model patent applications filed that year. ${ }^{27}$ This high incidence of patenting for both imitation (associated with utility model patents) and innovation indicates that China's firms are developing innovative capabilities that are enabling them to rapidly absorb the inflow of foreign technology.

Together the rapid rise in $R \& D$ spending and the rapid growth in patenting are key leading indicators of the capacity of China's economy to translate its growing resource base into new knowledge, which it can then embody in increasingly efficient production that draws it closer to international state-of-the-art methods. Figures 6 and 7 substantially round out the story of the catch-up of China's advanced industrial sector with the industrial capabilities of the OECD economies. The concentration of R\&D and FDI in China's coastal economy helps to explain why China's coastal provinces appear to enjoy the structural advantages in productivity growth and international technology catch-up depicted in table 7 and figure 3 .

\section{The Political Economy of China's Economic Growth}

In any country, the political system is important for economic growth, because it defines the structure and functioning of the institutional arrangements that shape incentives and economic performance. ${ }^{28}$ In China, a lowmiddle-income developing country whose transition from a planned economy remains incomplete, the functioning of the political system is critical in determining the nation's capacity to assign and clarify property rights. Clearly defined property rights are needed to strengthen incentives to accumulate and efficiently utilize economic resources, both labor and capital, including physical, financial, and human capital.

Table 10 identifies two bundles of institutional reforms that are particularly relevant to the ability of China's economy to accumulate and allocate the resources needed to reduce its productivity gaps. The first bundle relates to conditions that shape the capacity to reallocate labor from

27. The Chinese patent office grants invention patents and utility model patents; the latter have less stringent requirements and extend shorter protection than invention patents.

28. See North (1994). 
Table 10. Areas Requiring Institutional Reform in China

\begin{tabular}{|c|c|}
\hline Reform & Importance \\
\hline \multicolumn{2}{|c|}{ Institutional reforms affecting efficient labor reallocation } \\
\hline Reform of the hukou system & To facilitate rural-urban migration \\
\hline Land ownership reform & $\begin{array}{l}\text { To enable consolidation of small farms and } \\
\text { scale economies in farming and improve the } \\
\text { ability of farmers wishing to migrate to } \\
\text { liquidate their assets }\end{array}$ \\
\hline Reform of the social insurance system & $\begin{array}{l}\text { To increase labor mobility and facilitate } \\
\text { enterprise restructuring }\end{array}$ \\
\hline \multicolumn{2}{|c|}{$\begin{array}{l}\text { Institutional reforms affecting industrial restructuring } \\
\text { and technology development }\end{array}$} \\
\hline Bank reform & To improve the efficiency of capital allocation \\
\hline Regional integration & $\begin{array}{l}\text { To reduce impediments to factor mobility, } \\
\text { trade, and competition }\end{array}$ \\
\hline $\begin{array}{l}\text { Antitrust legislation and merger and } \\
\text { acquisitions legislation }\end{array}$ & $\begin{array}{l}\text { To facilitate enterprise restructuring and } \\
\text { encourage the creation of firm-level scale } \\
\text { economies }\end{array}$ \\
\hline Corporate governance reform & $\begin{array}{l}\text { To enhance firm efficiency and increase the } \\
\text { returns to innovation }\end{array}$ \\
\hline Intellectual property rights enforcement & $\begin{array}{l}\text { Continuous strengthening needed to speed the } \\
\text { transition from imitation to innovation }\end{array}$ \\
\hline
\end{tabular}

China's relatively backward, low-productivity sectors to higher-income sectors. These include elimination of the residency registration (hukou) system, the establishment of land ownership rights to facilitate the sale and consolidation of fragmented and unproductive agricultural plots, and the creation of a social insurance system. The second bundle of institutional arrangements relates to provisions that are needed to facilitate the development and diffusion of technology, the restructuring of enterprises, and more efficient capital utilization. For each of these institutions, table 10 identifies its importance for reducing the relevant productivity gap. The political factors that affect the likelihood of these institutional reforms being advanced are discussed later in this section. These generally consist of existing commitments that China's government has made and its increasing political responsiveness to China's residents, who have a stake in continued prosperity.

To illustrate the importance of clarifying and reallocating property rights for China's future growth trajectory, we focus on just one of the reforms identified in table 10, namely, the role of corporate governance reform. Table 9 underscored the important contribution made by the exit 
Figure 8. Distribution of Exiting and Entering Firms by Form of Ownership, 1996-98 to 2002-03

\section{Exits}

Percent of total

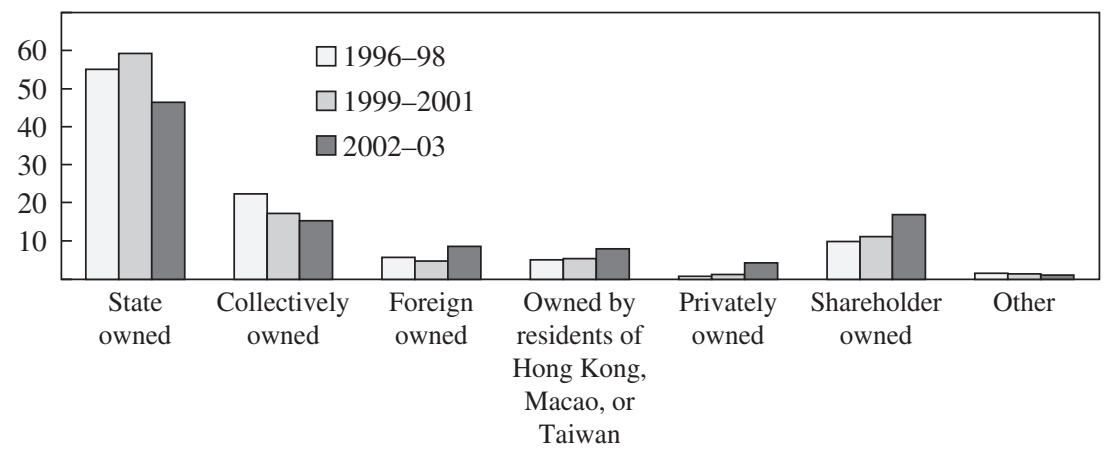

Entrants

Percent of total

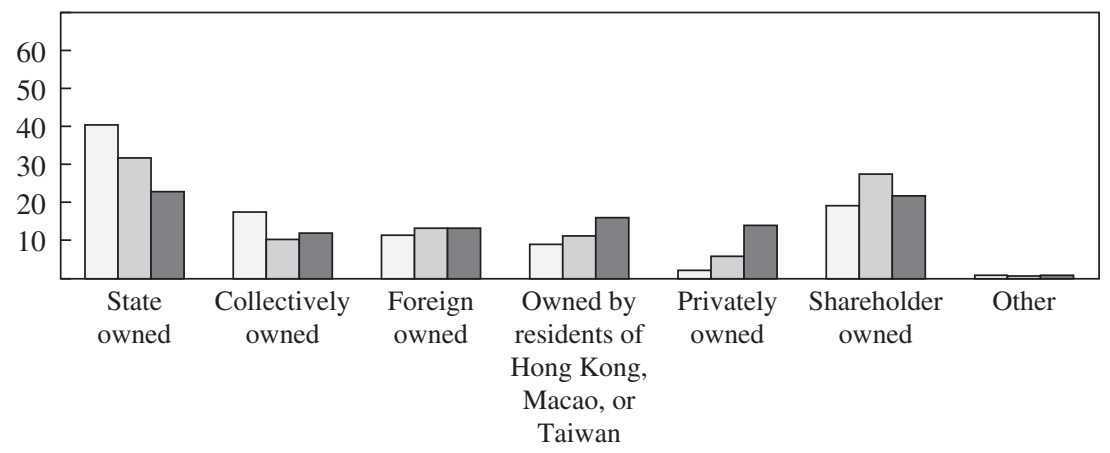

Source: NBS and authors' calculations.

and entry of firms to the advance of both labor and capital productivity in China's industrial sector.

To clarify the institutional character of the exit-entry phenomenon, we now compare the ownership structures of exiting and entering firms. Figure 8 shows that they are very different. During 1996-2003 the majority of exiting firms were state-owned enterprises, followed by collectively owned enterprises and shareholding companies. By comparison, in 2001-03 fewer than 23 percent of new entrants and about twice that proportion of exiting firms were state-owned enterprises. All forms of non- 
state and noncollective ownership are more likely to be found among entrants than among exiting firms. Specifically, entrants are far more likely to be private, shareholding, foreign, or overseas firms than their exiting counterparts. ${ }^{29}$ These results suggest that part of the exit-entry phenomenon is associated with restructuring involving a change in ownership form. There is a clear association between the institutional and political economy side of China's economy and its ability to create and sustain productivity growth through laws, regulations, procedures, and factor markets that are defined by the political system.

\section{How Sustainable Is China's Institutional Reform?}

How likely is China to sustain the momentum of reform along the institutional dimensions defined in table 10 ? We suggest that the momentum of institutional reform is likely to continue, for three interrelated reasons. The first is based on China's record of institutional reform over the past twenty-five years, during which the political leadership has continuously engaged in the institutional reforms needed to sustain economic growth. ${ }^{30}$ The historical record strongly suggests that China's political leadership is deeply vested in the reform process and will continue along the path of institutional change. The second reason is the set of prior commitments that frame Chinese law and the nation's political choices. Notable among these precommitments are China's membership in the World Bank and the International Monetary Fund and its accession to the WTO and the TRIPS agreement, which together require minimum standards with respect to openness, financial system reform, and enforcement of intellectual property rights.

The third reason why substantial institutional reform is likely to continue is that China's fast-emerging middle class and its growing force of entrepreneurs, who are now eligible to become Communist Party members, expect their political system and leaders to pursue policies that support sustained economic growth. Robert Barro finds support for the

29. Overseas funded enterprises are those with investment from residents of Hong Kong, Taiwan, or Macao. Firms with investment from residents of any other jurisdiction are called foreign-funded enterprises.

30. Jefferson and Rawski (1994) and Qian (2000), among others, focus on the underlying structural conditions that have driven China's reform process. 
notion that political reform is endogenously driven by economic variables. ${ }^{31}$ Using panel data from over 100 countries from 1960 to 1995, Barro concludes that the propensity for democracy is most robustly associated with a growing middle-class share of GDP, with years of primary schooling and a narrowing of the gap between male and female primary schooling, and with the absence of oil as an abundant natural resource. With China now enjoying the rapid growth of a middle class, with more females than males in primary school, and with a growing dependence on imported oil, China would seem to fit Barro's profile of a country that is on the threshold of important democratic innovations.

Our view is that although China has clearly not established an effective system of competitive political parties, the Communist Party's monopoly over political power has evolved from one that is near absolute to one that is, arguably at least, contestable. ${ }^{32}$ To the extent the Party's power is a contestable monopoly, and given that its legitimacy and its ability to resist those elements that might challenge its authority rest squarely on China's ability to sustain rising living standards and social stability, the Party's economic policy priorities and policy initiatives are likely to continue, however haltingly, to be responsive to demands for social and political reform.

According to one report, "Chinese officials believe they need between $7 \%$ and $8 \%$ of their $10 \%$ growth rate simply to ensure domestic stability through providing jobs for the wave of migrants coming to booming cities ... and services to restive rural communities." ${ }^{33}$ The list of institutional reforms needed to sustain productivity growth in China (table 10) and the list of reforms needed to buttress the Party's political legitimacyspecifically, the need to sustain rising economic prosperity and social order-are highly overlapping and interdependent. The experience of China's economic, institutional, and political reform process over the past two decades suggests a high likelihood that, through a series of challenges and responses and the learning associated with the reform process, facilitated by China's unusual openness to the flow of trade and ideas from the OECD countries, China's leadership will continue to advance institutional

31. Barro (1999).

32. These include Pei (1998) and Goldman (2005).

33. Frederick Kempe, "Thinking Global: Departing Zoellick Looks Back on Pending Business with China," Wall Street Journal, June 27, 2006, p. A10. 
reforms that will effectively complement and exploit the factors underlying the sources of productivity advance. ${ }^{34}$

This optimistic projection tries not to disregard the magnitude of a variety of serious challenges to China's economic and political systems no matter how able and responsive the country's political leadership. China's sustained high rate of growth carries with it serious negative spillovers. Among those that have been well documented both in academic studies and in the popular press are growing income inequality, environmental degradation, risk and insecurity associated with a fragmented social insurance system, and corruption associated with ill-defined and poorly enforced property rights. Such developments confront China's leadership with difficult tradeoffs that increase the risk of derailing the nation's economic progress. Moreover, failure to curtail the negative spillovers from rapid growth may undermine the legitimacy of the political system and its ability to pursue the institutional reforms needed to continue China's catch-up with the international technology frontier and the reductions in internal productivity gaps, both of which are needed to sustain overall growth and rising living standards. Although the system faces real threats, China's accomplishments at reform to date, combined with an emerging middle and entrepreneurial class that is rapidly accumulating the education and experience in a competitive international environment, provide reassuring evidence that China is creating the civic capital needed to respond effectively to the challenges and opportunities associated with its ongoing economic transformation.

\section{Implications and Conclusions}

We view China's economic advance as a process of reducing, in a more or less balanced way, several key productivity gaps. We find evidence that the pace of productivity catch-up varies substantially across these gaps. China's industrial economy is enjoying a rapid pace of catch-up with the world's industrial frontier. We further find large and growing differences in productivity between coastal industry and agriculture across China's regions. Productivity differences between coastal industry and the services sector in the four regions are not as great as those between industry and

34. See Perkins and Rawski (forthcoming) and Zheng, Bigsten, and Hu (2006) for other assessments of the reforms needed to sustain China's economic growth. 
agriculture, but the gaps are significant, and they are expanding. Although official Chinese data are likely to overstate the size and rate of increase of regional and sector productivity differences, our revised employment data also show large differences and a continuing spread in productivity gaps. Within China's industrial sector, we find evidence that the three noncoastal regions are making progress in closing the productivity gap with coastal industry. However, our analysis indicates that, at least in the medium term, manufacturing in the coastal region will maintain an insurmountable productivity lead over industry in China's other regions. Outside of industry, there is no evidence of a convergence of productivity across regions and sectors.

A key finding of this paper is that the main productivity gaps- the international gap, the gaps across regions within the industrial economy, and the industry-agriculture and industry-services gaps-all exhibit diminishing contributions to productivity growth as the gaps narrow. As these gaps further diminish, it is very probable that China's productivity growth, particularly along the coast where catch-up with the international frontier is occurring most rapidly, will slow.

It is instructive to compare China's current pattern of productivity gaps with those exhibited by South Korea and Taiwan when their GDP per capita reached one quarter that of the United States, a milestone China will achieve when its GDP reaches that of the United States. When South Korea and Taiwan reached this milestone, their industrial labor productivity was just one third the U.S. level. Since China's income per capita is presently only one twenty-fourth of the U.S. level, China's labor productivity will have to rise sixfold before it achieves a GDP per capita that is one quarter that of the United States. However, given that the industrial productivity of China's coastal region today is nearly one quarter that of the United States, an across-the-board sixfold scaling up of Chinese productivity would require coastal industrial productivity to reach an unattainable level of close to one and a half times that of the United States.

Clearly, as the industrial productivity of China's coastal region approaches that of the international frontier, China's GDP growth can be expected to slow sharply, and China will need to rely less on coastal industry as its engine of growth than it now does. This will require policies that more effectively integrate China's internal economy, to reduce the productivity gaps that now exist across its regions and sectors. Viewed 
from another perspective, in order for China's GDP to match that of the United States, China's economy will have to begin moving down the right-hand side of Simon Kuznets' inverted U-curve, reducing disparities in productivity and income across regions, sectors, and households. Today, compared with South Korea and Taiwan, China leans more heavily on its coastal industrial economy for overall catch-up. This disproportionate reliance on international catch-up, even as large productivity gaps and unrealized productivity and GDP growth potential persist within the Chinese economy, will become an increasingly serious impediment to China's development. Continued institutional reform and policy initiatives that shift the emphasis of China's rapid growth from the coastal industrial economy to the economic integration of its internal regions and backward sectors should be a top priority. 


\section{Comments and Discussion}

Barry P. Bosworth: In this paper, Gary Jefferson, Albert $\mathrm{Hu}$, and Jian $\mathrm{Su}$ discuss a wide range of issues that arise in evaluations of China's recent growth performance and future prospects. Indeed, the range is so broad that no one of these issues can be thoroughly examined within the context of a single paper. I will therefore focus on just a few.

The first part of the paper examines China's development on two margins: the labor productivity gap between China's coastal region and a global frontier, represented by a combination of manufacturing industries in Japan and the United States; and the relative labor productivity gaps among China's four major regions. With respect to the first issue, the authors' basic conclusion is that there has been considerable catch-up to the international frontier, but the gap is still very large. No one should quarrel with this conclusion, since China's economy has obviously been growing far more rapidly than the rest of the world. More controversially, the authors find that regional disparities in manufacturing productivity within China narrowed between 1995 and 2002, except for the northeast (table 2), where the gap with the leading coastal region has widened.

The comparisons are based on twenty-seven industries within manufacturing. International comparisons of levels of productivity at the individual industry level are extraordinarily difficult, especially for China, which has only recently agreed to participate in the World Bank-led International Comparison Program and still lacks comprehensive purchasing-powerparity estimates of GDP. Most international comparisons are limited to aggregate GDP, because the methodology needed to compute industryspecific conversion factors is very underdeveloped. An estimate of the purchasing-power-parity exchange rate has been cobbled together for China, 
but its manufacturing industries reflect a mixture of exporters, for which the commercial exchange rate would be applicable, and firms that produce for the domestic market. Furthermore, at even the most detailed classification grouping, firms produce very different products in China, Japan, and the United States. Thus, the international comparisons of productivity in the authors' table 2 and figure 1 should be handled with care. Within China, the labor market and the transportation system are not integrated across regions. This makes it hard to compare levels of value added per worker across regions, since wages for equivalently skilled labor may differ. However, their relative growth rates should still reflect any convergence that has occurred.

In tables 3 and 4 the authors shift to a data set that reports on both national and regional economic performance at a broad sectoral level: agriculture, industry, and services. Here another data issue emerges: the authors argue that, in recent years, as many as 80 million workers nationwide may have been misreported in the 2005 household surveys as working in agriculture when they are actually employed in industry or services. Such misclassifications could dramatically affect our understanding of the relative performance of Chinese agriculture and industry. The issue has been raised in several earlier papers, but the extent of the miscounting remains contentious. The authors deal with the problem by assuming that the misclassification of workers between agriculture and industry is uniform across regions, implying no effect on the regional comparisons of productivity performance presented in table 4 . This is not very helpful.

The results of this broad sectoral analysis appear to conflict with the authors' earlier conclusions based on manufacturing data, since the northeast now stands out with gains in labor productivity in industry between 1995 and 2004 that raise it above that of the coastal region. The industrial sector does include some important nonmanufacturing industries, where productivity growth may have been unusually rapid, and these industries are largely concentrated in the northeast. Even so, can it be that the region's industrial labor productivity grew at an 18 percent annual rate? The northeast also made significant gains on the coastal region in services. The other regions show modest convergence in industry and a mixed record in agriculture and services.

Most of the subsequent analysis is based on an intriguing micro panel data set of more than 20,000 large and medium-size enterprises. It might have been preferable to focus the paper entirely on a more thorough analy- 
sis of this data set. With these data in hand, the authors expand the analysis to include the role of capital and the computation of total factor productivity (TFP) at the level of individual firms. We are given no details on how their measure of capital services is constructed, but their estimate of TFP is based on a Cobb-Douglas production function with weights of 0.36 for the capital input and 0.64 for labor.

Initially, the authors focus on the interregional comparisons. They compute productivity at the firm level and examine the cross-regional differences in levels for 1995 and 2004 by regressing the firm-level data on productivity on a set of four regional categorical variables and controls for industry effects (tables 5 and 6). Here the basic story is again one of substantial regional convergence of both labor productivity and TFP over the period, and the northeast, the least efficient region in 1995, is shown as achieving the greatest catch-up. I would have thought that useful distinctions could have been made between large and small firms and between public and private firms. Later in the paper (figure 8), it becomes clear that the authors do have information on enterprise ownership characteristics. The low $R^{2} \mathrm{~s}$ indicate that there is much unexplained variation across these firms. Why were not some of these other potential determinants of productivity included?

In table 7 the authors aggregate their data to the level of twenty-seven industries and thirty-one provinces and relate the change in productivity between 1995 and 2002 to the initial gap relative to the international frontier. I do not know how they computed the efficiency gap, or how they aggregated the firm data, but they again demonstrate substantial catch-up. It is interesting that they obtain significant evidence that the industries that lag furthest behind show the greatest degree of catch-up, but the response of the coastal region is significantly greater than the all-China average. The finding of a stronger response in the coastal region is surprising in view of their earlier conclusion that the other regions were growing more rapidly. However, in this set of estimates they do not include regional variables. Furthermore, industries that show rapid productivity growth at the international frontier grow more slowly within China. The authors' conjecture that industries experiencing rapid productivity change offer less opportunity for catch-up is not convincing.

The micro panel data set contains annual information for the period 1995-2004 and is able to distinguish among new entrants, preexisting firms that survive the entire period, and firms that exit during the period. Differ- 
ences in the productivity performance of these entering, surviving, and exiting firms are the focus of the analysis reported in tables 8 and 9. The stated purpose is to determine the influence of firm turnover and the implied reallocation of resources on overall productivity growth. Given the emphasis on productivity levels in previous sections, I expected to see more discussion of the variation across firms (controlling for industry) and some measure of whether it declined during the ten-year period. ${ }^{1}$

However, the authors instead focus on the estimation of simple factor demand equations that relate the change in a factor input to the level of its own marginal product at the beginning of the period (table 8). They measure marginal productivities as being proportionate to the average productivities. They restrict the sample to firms that have survived over the full period, and they estimate the factor demand equations for two subperiods. The coefficients on the initial factor productivity level are positive for both the change in labor and the change in capital, but the effort to relate the growth in value added to the initial level of TFP results in a negative coefficient. Similarly, the change in TFP is negatively related to its initial level.

The authors argue that the unexpected negative coefficient is consistent with catch-up by the low-productivity firms. However, it might also be interpreted as showing the inadequacy of the underlying model, since one is left with the inference that high-productivity firms increase their use of labor and capital but reduce their output. The analysis is expanded in table 9 to include exiting and entering firms, but the data for such firms appear only in the year in which their status changed. That is, entering firms are those that were present in period $t$, but not period $t-1$, and exiting firms are those present in period $t$ but not period $t+1$. This would seem to be a very restrictive definition for many reasons, and it would seem a much better approach to examine the performance of entering and exiting firms for years other than the transition year.

Exiting firms turn out always to be the worst performers, and new firms have faster TFP growth than surviving firms in all three periods, and faster growth in labor productivity except in 2002-04. These results are as one would expect, but we are provided with no estimate of the contribution of firm births and deaths to the overall growth of productivity either at the

1. Hsieh and Klenow (2006) used a similar data set to highlight the wide variations in productivity of Chinese firms and the potential contribution that reductions in this dispersion could make to overall productivity growth. 
level of an industry or for the full sample. We are told that both entrances and exits were frequent, and that the number of entrants and exits was roughly equal, but we know nothing of their size.

Finally, what the authors call capital productivity is simply the outputcapital ratio. I was surprised to observe in figure 5 that the growth of output exceeded that of the capital stock in this data set and that the output-capital ratio rose substantially after 1997, despite the incredible rates of investment that China has sustained over the past decade.

The remainder of the paper addresses some issues concerning the sustainability of China's growth. Much of that discussion seems to be drawn from an earlier paper by one of the authors that addresses R\&D and patenting behavior in China. However, given the large remaining productivity gaps demonstrated between Chinese firms and their international competitors, China should be able to sustain its growth for many years through technological catch-up, without the need to focus on new innovations.

Gustav Ranis: This paper is laudable in its aims, ambitious in its scope, and prodigious in the energy expended on it, but somewhat disappointing in its execution. Its objective, to parse out the sources of China's astonishing past growth and its prospects for the future, is unexceptionable. China has made a dramatic recent entry onto the international scene, economically and politically as well as strategically. Consequently, there is a lot of discussion, in the professional economics literature as well as among policy experts, concerning the sources of that performance and, even more, concerning the system's prognosis, because China is now seen as a major player, whether as a brand new locomotive for the global economy or as a brand new threat to the established international economic order.

Gary Jefferson, Albert $\mathrm{Hu}$, and Jian Su have chosen to analyze China's past and future by examining the extent of catch-up, both of China's interior toward its coastal, externally oriented, provinces, and of the latter toward the international technology frontier represented by either the United States or Japan, depending on the industry. At times, the authors refer to multiple gaps, between regional agriculture and coastal industry, between regional services and coastal industry, between interior industry and coastal industry, and between coastal industry and the international frontier. However, they frame their analysis, in what they call the "basic model," in terms of only two gaps, international and internal, and this is a source of some confusion. 
Following Edward Denison, the authors first place heavy emphasis on the catch-up of China's coastal industries toward the international frontier. Since the coastal provinces are the most economically advanced, international convergence is not likely to be very pronounced, but, so the argument goes, they give rise to externalities such as technical diffusion that narrow the internal gaps and help to sustain over time the impact of the coast's gradual convergence with the frontier.

I have a basic problem with any definition of technological catch-up that is expressed in terms of labor productivity differentials. For example, the authors find that industrial labor productivity in 2002 in China's advanced coastal provinces was less than a quarter that in the United States or Japan. Defining technology gaps in this fashion is highly questionable, since one would expect rich countries to exhibit much higher industrial capital-labor ratios, and therefore higher labor productivity. The much preferred measure would seem to be differences in total factor productivity (TFP), independent of the extent of capital deepening. Simply substituting labor productivity for TFP requires some rather heroic assumptions concerning the constancy of relative income shares or factor price equalization.

Indeed, in all their treatment of productivity gaps, the authors appeal to factor reallocation, presumably with technology fixed, as a source of TFP growth. In their analysis they calculate the marginal productivity of labor as proportional to average labor productivity. If they were truly dealing with the marginal rather than the average productivity of labor, the authors' argument that aggregate TFP can be enhanced, even in the unlikely absence of any technical change, simply by reallocating labor in ways that eliminate existing gaps in marginal product, would make sense. But this is not what the authors have in mind. Estimates of TFP that exclude the contribution of innovation and rely entirely on reallocation are not realistic even in the case of the interaction between domestic agricultural and nonagricultural production (see below), and they are certainly inconsistent with the authors' emphasis on FDI, R\&D, and patents when dealing with the catch-up of China's coastal industries to the international frontier. As their borrowed table 1 powerfully illustrates, factor reallocation represents only one, and by no means the dominant, component of the TFP residual in virtually all countries.

In their empirical analysis, the authors deal in turn with each of several of the gaps they have suggested as relevant. With respect to the international gap, they address two important issues: Has the existence initially of 
a sizeable productivity gap caused an observable process of convergence? And does the resulting reduction of that gap over time imply a decline in China's future industrial productivity growth? The authors find that the larger the gap, the larger the catch-up in all of China's regions. But they also find that China's coastal industry enjoys higher rates of productivity growth than the more backward regions, which runs counter to the conventional convergence story. To explain this, the authors go outside their model, invoking higher concentrations of FDI and R\&D as well as certain locational and industrial agglomeration advantages in the coastal region. But these are the very factors that directly determine endogenous TFP rather than labor productivity.

The authors find, using data for twenty-seven Chinese industries and thirty-one provinces, that China's industrial labor productivity has converged toward the international frontier in recent years. For example, labor productivity in the coastal region moved from one ninth of the international frontier in 1995 to one fourth in 2002, "demonstrating the degree of catchup." However, as already pointed out, this result is likely due in large part to the more rapid pace of capital accumulation in China than in the United States or even Japan: investment in China has exceeded 40 percent of GDP in recent years. Even if we accept the authors' definition of catch-up and focus on the coastal region primarily (as in the top panel of their figure 1), it would have been helpful to examine why, as they note, the food, beverage, and tobacco industry stands out, in having labor productivity that is ten times that of industry as a whole. Is that because of an unusually high capital-labor ratio in that industry, or because of an unusually high rate of profits caused by government-imposed barriers to entry, as they claim?

The authors next discuss a variety of internal productivity gaps: between agriculture and domestic industry, between industry and services, and across regions within the services and industrial sectors, but, confusingly, they claim to empirically examine only two of these. Comparing domestic agriculture and industry, they find (table 3) that the ratio of industrial to agricultural labor productivity rose from 6.1 in 1980 to 7.1 in 2005, after initially declining with the shift from communes to the responsibility system in agriculture. However, with agricultural labor presumably largely unskilled, any comparison with "average industrial workers" rather than exclusively with reallocated unskilled industrial workers (for example, in construction or textiles) makes very little sense. In addition, I have a problem with the authors' reallocation effect, which is related mainly to 
the size of the productivity gap $g$ and the fraction $\beta$ of labor in the lowproductivity agricultural sector (see their equation 2 and figure 4). The authors neglect the possibility of technological change in agriculture, which historically almost inevitably accompanies the labor reallocation process. Moreover, I fail to see why the fraction of the population in agriculture should affect the annual rate of reallocation. After all, that rate depends less on how many workers are available for transfer in any one year than on their ability to move and be absorbed by higher-productivity nonagricultural activities. This is not to dispute the point that the bargains for GDP growth arising from labor reallocation in a dualistic economy are likely to diminish over time as the agricultural labor surplus itself diminishes.

The conceptual and empirical core of the paper, dealing with the internal productivity gaps across nonagricultural sectors, is presumably to be found in the implementation of their equations 3 to 6 . However, the relevance for gap reduction of equations 3 and 4, which indicate how initial marginal factor productivities yield changes in the subsequent demand for labor and capital, is not at all clear to me. Equations 5 and 6, which do bring in TFP, bear a family resemblance to the Solow equation, even though the rates of growth of both labor and capital inputs are not included, and even though we know TFP in that context to be an exogenous residual. It is also here where the later discussion of FDI, R\&D, and patenting could have been introduced to provide explicit endogenous behavioral elements.

The authors follow this discussion with a very interesting and novel analysis, based on rare primary data, of the contribution of the turnover (exit and entry) of firms to labor productivity change, by comparing these firms with those that survive over the same 1995-2004 period. Not surprisingly, exiting firms nearly always exhibit substantially lower, and entering firms substantially higher, productivity than survivor firms. Later on, the authors interestingly identify many of the exiting firms as state enterprises and many of the entrants as restructured or greenfield private enterprises. Two questions arise, however: First, is it reasonable to believe that out of a total annual population of 22,000 to 27,000 firms, more than 16,000 $(146,000 \div 9)$ either entered or exited each year from 1996 to 2004? Moreover, as the authors admit, the number of firms gives no indication of the relative size of the three categories under discussion.

A potentially more serious issue arises with respect to the NBS panel used for the analysis that includes only large and medium-size enterprises. As Jian Gao and Jefferson acknowledge elsewhere, "the vast majority of 
these [enterprises in China's industrial sector] are small household enterprises." This must be especially true for the township and village enterprise sector and the rapidly growing private enterprise sector over the most recent decade. The exclusion of these firms from the analysis must cast considerable doubt on the findings.

Finally, in their discussion of the sustainability of China's productivity growth, the authors return to defining technical progress in terms of labor productivity. I agree that there continue to exist large opportunities to reallocate labor from agriculture to other sectors, and undoubtedly these are best expressed in terms of technological and institutional changes. There follows a section on "China's Science and Technology Takeoff," which seems to ask what changes in R\&D or in patenting have caused the changes in China's industrial TFP. The authors accept the empirical regularity of a "science and technology takeoff" when R\&D reaches 1 percent of GDP, and they provide some interesting and generally plausible arguments as to why, with the help of R\&D and FDI inflows, China has already reached this point.

Here again, however, the published R\&D figures, which focus entirely on the official reports of large and medium-size firms, public and private, do not really convey a credible indication of a country's true R\&D activity. For example, in the other East Asian economies cited in the paper, the kind of informal blue-collar R\&D that takes place on the factory floor and in the repair shop has been shown to be extremely important in generating the adaptive technical changes that are often less than spectacular individually, but massive, and usually labor-absorbing, in the aggregate. ${ }^{2}$ The ensuing discussion of patents indicates not only that FDI-related foreign patents played a major role in stimulating domestic invention patents, but indeed that these were dwarfed by the explosion of relatively low-inventivenessthreshold utility patents, presumably heavily concentrated in smaller firms. My educated guess would be that these utility models, in China as earlier in the case of Japan, amount to more than simple imitations (or reverse engineering); rather, they also represent individually modest but, in toto, massive adaptive changes in both the process and product quality dimensions. Unfortunately, the paper's interesting discussion of R\&D, FDI, and patenting intensity is not at all integrated with the rest of the paper. It is, of course, no surprise that these variables are generally weighted more heav-

1. Gao and Jefferson (forthcoming).

2. Ranis (1990). 
ily in the coastal provinces, but their precise impact on the closing of the various gaps and China's overall growth trajectory is not really demonstrated. And again, they could be modeled as contributing directly to TFP, not to the various factor productivities.

Finally, although I applaud the authors' effort, at the end of the paper, to include some important political economy and institutional dimensions, that discussion is necessarily ex cathedra. I find myself in full agreement with much of their argument - that to sustain its growth China needs to take into account such constraints as a worsening income distribution, environmental degradation, uncertain property rights (especially in agriculture), corruption, and lagging political reforms, and that even under optimistic assumptions about continued institutional reforms (and the authors are clearly optimistic), the shrinkage of China's various productivity gaps, especially the international one, is likely to mean smaller contributions to overall growth in the future. After all, what successful middle-income developing country has been able to maintain real growth rates in the 8 to 10 percent range as it approaches economic maturity?

General discussion: William Nordhaus complimented the authors on their analysis of Chinese firms' productivity, which provided valuable insights into the sources of China's remarkable growth. But he also expressed reservations about some of the more aggregate results. Because much of the underlying data are constructed using Laspeyres indexes, estimates of productivity growth in the Chinese economy and its various sectors are biased upward. Edward Denison showed long ago that the increase in productivity that results from moving labor from low-productivity to high-productivity sectors largely disappears when the more appropriate chain-weighted quantity indexes are used. This increase in measured productivity, or "Denison effect," can be quite large, accounting for over 1 percentage point of reported productivity growth in Italy from 1952 to 1960, for example. Nordhaus noted that the Chinese national accounts use Laspeyres indexes with 1990 planning prices; he expected that a substantial fraction of productivity growth, perhaps on the order of two-thirds of a percentage point, would disappear once the Chinese move to chain-weighted indexes.

Nordhaus also pointed out that the output indexes used by the authors need to take into account differences in price levels across regions and firms. It is not clear what methodology Chinese officials follow to deal with this issue, and no method is completely satisfactory. For example, the 
methodology based on the consumer price index, where each model has to be matched by outlet, has difficulty dealing with such differences.

Nordhaus remarked that cross-country comparisons of the level of productivity, and by implication estimates of the rate of convergence, are even more problematic than within-country comparisons. The authors do not attempt to adjust for the difference between purchasing-power-parity (PPP) and market exchange rates. In the case of China, it seems likely that using the market exchange rate underestimates productivity and overestimates the gap between China and the industrial frontier, especially for industries that produce mostly nontradables. A further difficulty in the level comparisons is that domestically supplied inputs, such as structures, are likely to be undervalued. Nordhaus noted, however, that the available PPP data for China are far out of date: the Penn World Tables base their PPP estimates on Irving Kravis's data from 1975, with some updates, including from a bilateral city comparison from 1993 between Hong Kong and Guangdong; a scheduled ten-city study is still pending. Without more recent data, reliable PPP adjustments are not feasible.

David Backus thought it would be interesting to decompose productivity growth in Chinese industry into components that capture changes due to firm entry, and components that capture exit changes in surviving firms. He mentioned studies by Jan de Loecker and James Schmitz, Jr., that looked at productivity changes following transitions that made the environment more competitive. Both these authors found not only that some of the least productive firms exited, but also that relatively unproductive firms became more productive. Backus wondered whether changes in regulations in China had had similar effects and had resulted in less dispersion in productivity at the industry level. Also, given the large dispersion in firm productivity within industries, it would be interesting to know whether the low-productivity firms in the present authors' sample also have bank ties of the kind explored by Wendy Dobson and Anil Kashyap in their paper in this volume.

Wendy Dobson wondered whether the Chinese authorities are today actually devoting resources to the creation of new knowledge, or if they are still primarily preoccupied with catching up with the existing stock of knowledge. Gary Jefferson replied that his impression was that the Chinese authorities' intention is to put more emphasis on creation of new knowledge. Indeed, from the patent data it seemed that the firms themselves are focusing more on invention than they have in the past. 


\section{References}

Barro, Robert J. 1999. "Determinants of Democracy." Journal of Political Economy 107, no. 6: S158-83.

Brandt, Loren, Xiaodong Zhu, and Chang-Tai Hsieh. Forthcoming. "Growth and Structural Change in China." In China's Great Transformation, edited by Loren Brandt and Thomas G. Rawski. Cambridge University Press.

Cai, Fang. 2004. "Consistency of China's Statistics on Employment: Stylized Facts and Implications to Public Policies." Chinese Journal of Population Science no. 3, pp. 2-10.

Denison, Edward F. 1967. Why Growth Rates Differ: Postwar Experience in Nine Western Countries. Brookings.

Ding, Xiaoquan. 2001. "The Contribution of the Transfer of Surplus Labor in Countries to China's Economy Growth." Observer of Chinese Countries (February) (in Chinese).

Du, Yang, and Albert Park. 2005. "Blunting the Razor's Edge: Regional Development in China." Beijing and Ann Arbor, Mich.: Chinese Academy of Social Sciences Institute of Population and Labor Economics and University of Michigan.

Evenson, R., and G. Ranis, eds. 1990. Science and Technology: Lessons for Development Policy. Boulder, Colo.: Westview Press.

Fagerberg, Jan. 1994. "Technology and International Differences in Growth Rates." Journal of Economic Literature 32, no. 3: 1147-75.

Gao, Jian, and Gary H. Jefferson. Forthcoming. "Science and Technology Takeoff in Theoretical and Empirical Perspective." Asia Pacific Business Review.

Goldman, Merle. 2005. From Comrade to Citizen: The Struggle for Political Rights in China. Harvard University Press.

Holz, Carsten A. 2006. "Why China's Rise Is Sustainable.” Far Eastern Economic Review 169, no. 3: 41-46.

Hsieh, Chang-Tai, and Peter J. Klenow. 2006. "Misallocation and Manufacturing TFP in China and India." Paper presented at the Stanford Center for International Development 2006 Pan Asia Conference, Palo Alto, Calif., June 1-3.

$\mathrm{Hu}$, Albert Guangzhou, and Gary H. Jefferson. 2006. "A Great Wall of Patents: What Is behind China's Recent Patent Explosion?" Singapore and Waltham, Mass.: National University of Singapore and Brandeis University.

Jefferson, Gary H., and Thomas G. Rawski. 1994. "Enterprise Reform in Chinese Industry." Journal of Economic Perspectives 8, no. 2: 47-70.

Jefferson, Gary H., and Jian Su. 2006. "Privatization and Restructuring in China: Evidence from Shareholding Ownership, 1995-2001." Journal of Comparative Economics 34, no. 1: 146-66.

Jones, Charles I. 1995. "R\&D-Based Models of Economic Growth." Journal of Political Economy 103, no. 4: 759-84. 
Maddison, Angus. 1998. Chinese Economic Performance in the Long Run. Paris: Organization for Economic Cooperation and Development.

National Bureau of Statistics of China (NBS), Department of National Economic Accounting. 1997. Historical Data on China's Gross Domestic Product, 1952-1995. Dalian: Dongbei University of Finance and Economics Press (in Chinese).

1999. Comprehensive Statistical Data and Materials on 50 Years of New China. Beijing: China Statistical Press.

Naughton, Barry. 2007. The Chinese Economy: Transitions and Growth. MIT Press.

North, Douglass C. 1994. "Economic Performance through Time." American Economic Review 84, no. 3: 359-68.

Pei, Minxin. 1998. "The Growth of Civil Society in China." In China in the New Millennium: Market Reforms and Social Development, edited by James A. Dorn. Washington: Cato Institute.

Perkins, Dwight H., and Thomas G. Rawski. Forthcoming. "Forecasting China's Economic Growth over the Next Two Decades." In China's Great Transformation, edited by Loren Brandt and Thomas G. Rawski. Cambridge University Press.

Qian, Yingyi. 2000. “The Process of China's Market Transition (1978-1998): The Evolutionary, Historical, and Comparative Perspectives." Journal of Institutional and Theoretical Economics 156, no. 1: 151-71.

Ranis, Gustav. 1990. "Science and Technology Policy: Lessons from Japan and the East Asian NICs." In Science and Technology: Lessons for Development Policy, edited by Gustav Ranis and Robert E. Evenson. Boulder, Colo.: Westview Press.

Rawski, Thomas, and Robert Meade. 1998. "On the Trail of China's Phantom Farmers." World Development 26, no. 5: 767-81.

Wang, Xiaobing, and Yunhua Liu. 2005. "Technological Progress and Chinese Agricultural Growth in the 1990s." China Economic Review 16, no. 4: 419-40.

Zheng, Jinghai, Arne Bigsten, and Angang Hu. 2006. "Can China's Growth be Sustained? A Productivity Perspective.” Working paper. Göteborg University, Department of Economics. 